DOI: http://dx.doi.org/10.22201/iie.18703062e.2017.1.2593.

\title{
Cifra, signo y artilugio: el "ocho" de Guadalupe
}

\section{Figure, Sign and Contrivance: The "Eight" of the Virgin of Guadalupe}

Artículo recibido el 8 de marzo de 20I6; devuelto para revisión el is de agosto de 20I6; aceptado el I2 de septiembre de 20I6. http://dx.doi.org/IO.2220I/iie.18703062e.2017.I.2593

Jaime Cuadriello Universidad Nacional Autónoma de México-Instituto de Investigaciones Estéticas, México, cuajrat1@unam.mx

Líneas de investigación Arte novohispano; cultura simbólica; estudios regionales; guadalupanismo.

Lines of research Art of New Spain; symbolic culture; regional studies; Guadalupanism.

Publicaciones más relevantes Las glorias de la república de Tlaxcala: o la conciencia como imagen sublime (México: Universidad Nacional Autónoma de México-Instituto de Investigaciones Estéticas/Museo Nacional de Arte, 2004); Zodíaco mariano: 250 años de la declaración pontificia de María de Guadalupe como patrona de México (México: Museo de la Basílica de Guadalupe/Museo Soumaya, 2004); El éxodo mexicano: los héroes en la mira del arte, coordinación de Jaime Cuadriello (México: Museo Nacional de Arte/Universidad Nacional Autónoma de México-Instituto de Investigaciones Estéticas, 2010); El divino pintor: la creación de María de Guadalupe en el taller celestial (México: Museo de la Basílica de Guadalupe, 200I); Maravilla americana. Variantes de la iconografía guadalupana (México: Museo de la Basílica de Guadalupe/Patrimonio Cultural de Occidente, 1989).

Resumen Desde la reconsideración de los estudios asincrónicos y la resignificación de las imágenes, propuestos por Georges Didi-Huberman, en este estudio de caso se explora la emergencia de una "imagen espontánea”: el número ocho que en el tobillo de la imagen guadalupana de México detectaron el pintor Miguel Cabrera y el historiador Mariano Fernández de Echeverría y Veytia. Una cifra enigmática que devino en signo exegético y acabó, por efecto de los juegos retóricos, en un artilugio de hondo mensaje profético, incluso libertario. El número ocho, además, resultó una práctica pictórica inherente al concepto de vera effigie o casi una manera de autentificar las copias del ayate de Juan Diego. Este signo devoto y promisorio no escapó, sin embargo, a la crítica ilustrada y racionalista del siglo xviII pese al prestigio del pintor que lo reportó en su dictamen Maravilla americana de 1756 . 
Palabras clave guadalupanismo; imagen sagrada; Miguel Cabrera; Mariano Fernández de Echeverría y Veytia; José Ignacio Bartolache; fray Servando Teresa de Mier.

Abstract Reviewing studies of the anachronism and the re-signification of images proposed by Georges Didi-Huberman, this article explores the emergence of a "spontaneous image": the number eight painter Miguel Cabrera and historian Mariano Fernández de Echeverría y Veytia detected on the Virgin of Guadalupe ankle. An enigmatic figure which became, first, an exegetical sign, and finally—as an effect of rhetorical exercises - a device conveying a deep prophetic, even libertarian, message, the number eight also established itself as a pictorial practice inherent in the concept of vera effigie or as means of certifying copies of Juan Diego's cloak (known as tilma or ayate), which remained current until the early twentieth century. This sign was not immune to the enlightment and rationalist critique of the eighteenth century, despite the prestige of the painter who reported it in his book Maravilla americana of 1756 .

Keywords Virgin of Guadalupe; Sacred Image; Miguel Cabrera; Mariano Fernández de Echeverría y Veytia; José Ignacio Bartolache; Servando Teresa de Mier. 
DOI: http://dx.doi.org/10.22201/iie.18703062e.2017.1.2593.

\author{
JAIME CUADRIELLO \\ UNIVERSIDAD NACIONAL AUTÓNOMA DE MÉXICO \\ INSTITUTO DE INVESTIGACIONES ESTÉTICAS \\ MÉXICO

\section{Cifra, signo y artilugio: el "ocho" de Guadalupe}

A mis patricios compadres

\title{
Inspecciones, deducciones y asombros
}

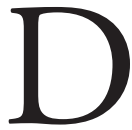
esde la década de I680, los copistas de la imagen de la Virgen de Guadalupe solían emplear un calco en papel aceitado, tomado directamente del Sagrado Original, para transcribir en sus facsímiles "el diseño". De esta suerte, otorgaban los mismos contornos, trazos, medidas, rayos, estrellas, plecas y demás atributos que hacían que estos "verdaderos retratos" fueran sumamente apreciados de este y del otro lado del Atlántico (fig. I). Apegados a su estatuto de icono revelado, estos traslados transmitían las mismas propiedades de inmanencia, empatía y presencia acordes al pensamiento neoplatónico que sostenía que las sagradas imágenes guardaban, por un principio de similitud, las mismas propiedades honoríficas respecto a su original y así quedaban mejor vinculadas a su prototipo celestial. Estos venerables retratos, pues, procuraban ser lo más fielmente posibles a la tilma de Juan Diego excepto por lo que toca a los materiales y los colores, ya que su registro no estaba al alcance de todos los artistas ni mucho menos la posibilidad de examinarlos a su antojo.

No obstante las inspecciones que realizaron maestros de pintura en I666, abierta la vidriera que resguardaba la imagen guadalupana, tan sólo Miguel 
DOI: http://dx.doi.org/10.22201/iie.18703062e.2017.1.2593.

158

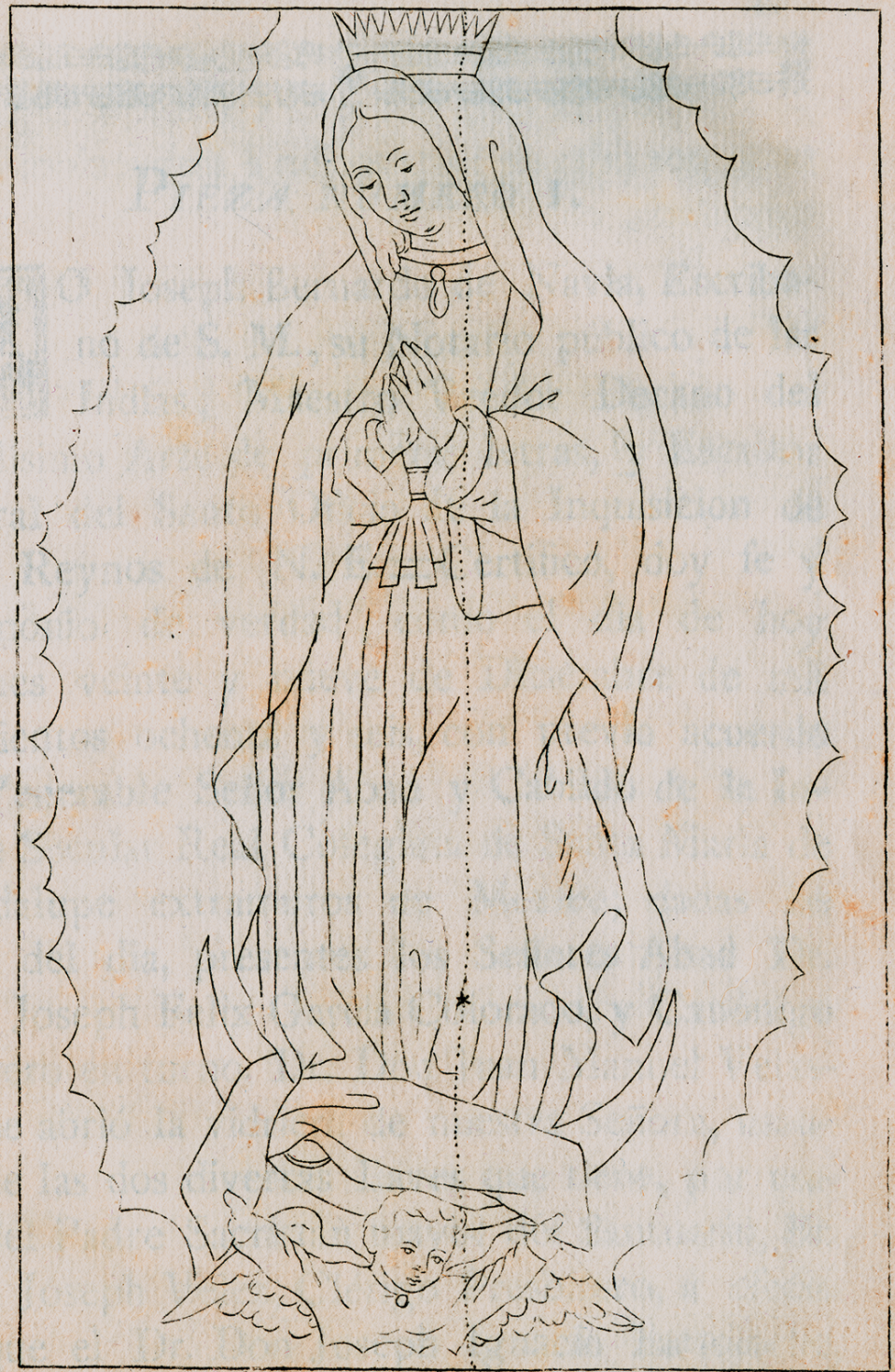

Esta Lamina es solo para representar el viage, ò hilo, de la cas: zura de los dos paños del Ayáte Guaidalupano, como hoy exíste 1787.

I. Anónimo novohispano, Esta lámina es solo para representar el viage, ó hilo de la costura de los dos paños del Ayate Guadalupano, como hoy existe, $1787,16 \times 9.5 \mathrm{~cm}$, tomado de Bartolache, Manifiesto satisfactorio (vid infra n. I8), [109]. Colección particular, Ciudad de México. 
DOI: http://dx.doi.org/10.22201/iie.18703062e.2017.1.2593.

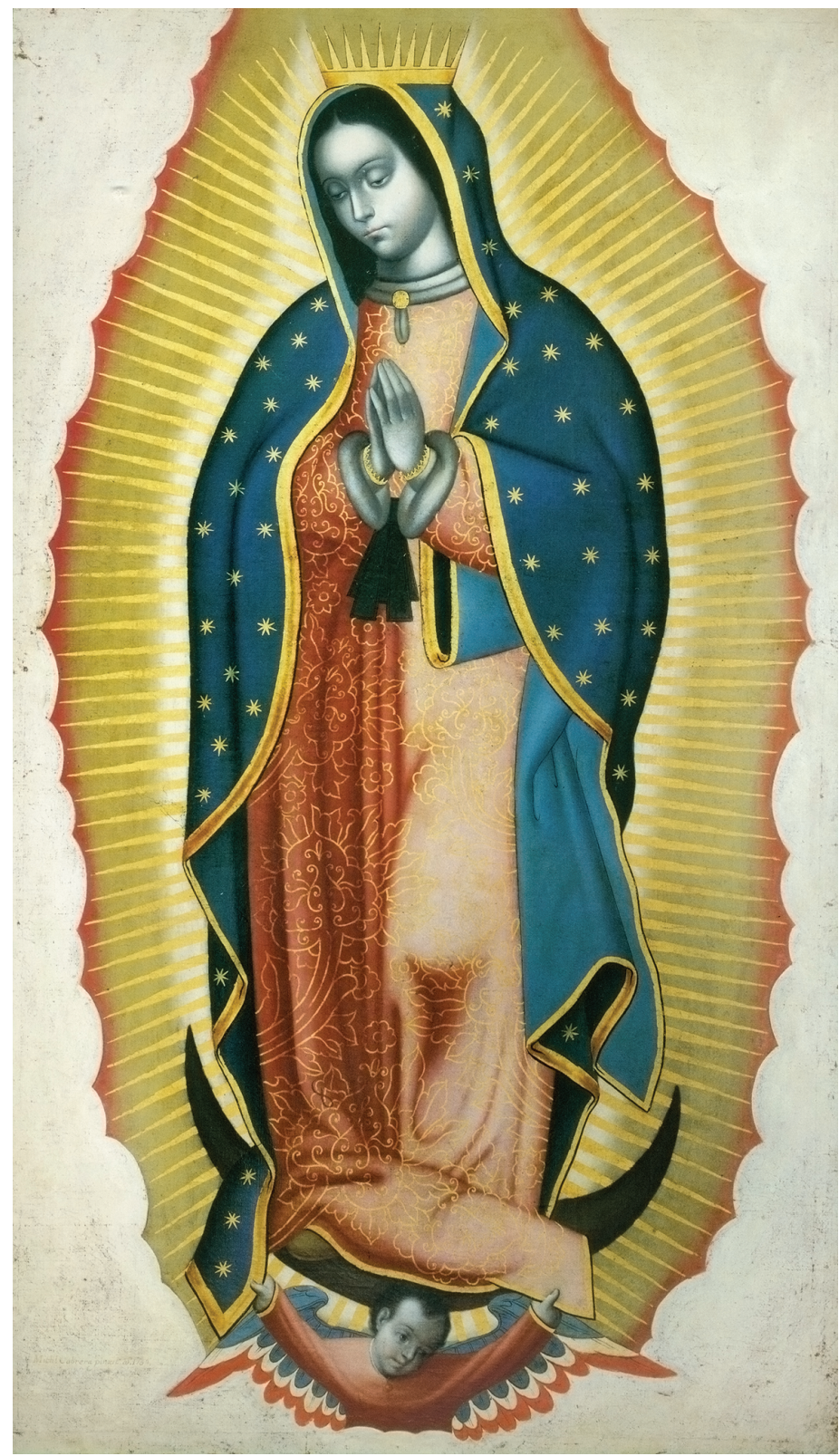

2. Miguel Cabrera, Imagen de la Virgen de Guadalupe, $1759,185 \times 100 \mathrm{~cm}$. Colección particular, Ciudad de México. (CFoto: Fernando Herrera. 
DOI: http://dx.doi.org/10.22201/iie.18703062e.2017.1.2593.

I60

Cabrera casi un siglo después tuvo a sus anchas - y en repetidas ocasiones-, la posibilidad de aproximarse y hacer operaciones técnicas para igualar al modelo. Cabrera pudo confirmar medidas, realizar templas sobre los colores y hacer un minucioso estudio de la técnica y sus materiales, acompañado por seis colegas durante la jornada del 30 de abril de 175 I. A partir de entonces, los colores de las copias variaron notablemente tanto en las encarnaciones como en el atavío: basta comparar dos copias de su mano antes y después de este examen (fig. 2). ${ }^{I}$ No es éste el lugar para detenernos en su curioso estudio y el uso que hizo de la teoría de la pintura para acreditar esta inexplicable condición, mixtura de técnicas y conservación admirable, pero sí para detenernos en el reporte más desmedido y que desencadenó un debate de significados, al avalar o descalificar la condición non manufacta de la pintura y que, al cabo, puso en evidencia las atribuciones de los pintores en un campo que no era el suyo: la exégesis. Cabrera se detuvo en un rasgo insólito del cuadro que, en su dictamen llevado a Roma y publicado cinco años después, resultó toda una novedad y causa de innumerables asombros:

Sobre el pie derecho a poca distancia en el cañón principal, que descansa sobre él en una quiebra, que hace, tiene un número ocho índice a mi ver, con que nos acuerda, que su portentosa, y primera aparición fue dentro de la Octava de su Concepción Purísima, de cuyo Misterio es la más fiel, y ajustada copia: si no es que diga, que este número no quiere decir, que es la Octava Maravilla del Mundo (fig. 3 ). ${ }^{2}$

Se trataba de un detalle aparentemente nimio que había pasado inadvertido a los autores y pintores de antańo y el cual, por su rareza en la propia técnica de la pintura (o que la afeaba), pienso, tuvo que justificarse con esa disquisición que satisfacía tanto a la curiosidad como a la perfección y así el ocho quedó incorporado al canon de reproductibilidad de las subsecuentes veras effigies.

I. Se trata de una imagen de la Virgen de Guadalupe de Miguel Cabrera pintada antes de I75I donde se aprecia este cambio radical y que aquí no se reproduce por la negativa del Museo de la Basílica de Guadalupe (véase nota bene), sin embargo, el lector puede apreciarla en: Jaime Cuadriello, Zodíaco mariano: 250 años de la declaración pontificia de María de Guadalupe como patrona de México (México: Museo de la Basílica de Guadalupe/Museo Soumaya, 2004), 5I.

2. Miguel Cabrera, Maravilla americana o conjunto de raras maravillas, observadas con la dirección de las reglas del arte de la pintura en la prodigiosa imagen de Nuestra Señora de Guadalupe de México (México: Imprenta del Real y más Antiguo Colegio de San Ildefonso, 1756), 25. 
3. Virgen de Guadalupe [detalle de la imagen original], siglo xvı.

Insigne y Nacional Basílica de Santa María de Guadalupe, Ciudad de México. (CFoto: Emeterio Guadarrama.

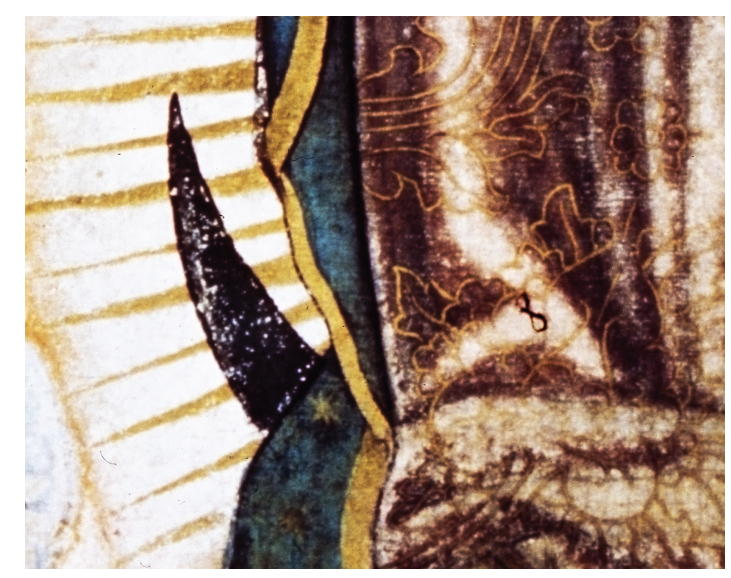

Esto lo escribía Cabrera justo en el parágrafo o subcapítulo dedicado a examinar el diseño de la imagen, es decir, las virtudes del trazo, la proporción y la composición y donde desahoga las posibles imperfecciones o críticas que se le habían hecho a la figura. Entre otras, la aplicación del dorado en plecas y motivos que parecían una intromisión incómoda y que Cabrera explicaba como una suerte de labrado exquisito; en cambio, ese ocho arrojado sobre el tobillo sí que lo percibía como una rareza o un defecto intrusivo que rompía cualquier regla de la pintura, incluso de la ornamentación tan regular y delineada de los arabescos de la túnica. Caído de lado, abierto en uno de sus rasgos, formando un relieve pastoso y elevado sobre la capa pictórica, el ocho necesitaba de una justificación técnica, pero a fin de cuentas simbólica y misteriosa. Y éste fue el tono de la respuesta del pintor, que levantó la sospecha de que su pluma estaba "movida" por sus asesores jesuitas. Como se ve, una de las razones esgrimidas descansaba en la doctrina de la mariología (una data que se registraba en la octava de la Inmaculada, cuando entre un ocho y un doce de diciembre tuvo lugar el portento) y la otra, culterana y erudita: la octava maravilla del mundo porque toda la imagen era un monumento admirable e inefable y, como tal, destinado a pervivir y maravillar los sentidos. Esta última afirmación pasaría como un tópico laudatorio y autocelebratorio, pero la primera, al datar el misterio de la Concepción en un rasgo, proponía a los devotos un significado numerológico con apoyatura de cierta historicidad. Era realmente un recurso 
DOI: http://dx.doi.org/10.22201/iie.18703062e.2017.1.2593.

I62

más retórico que adivinatorio, pero una atribución más propia de los predicadores que de los pintores (salvo cuando estos últimos entraban al género de la tratadística y en su papel de "pintor cristiano" podían ocuparse de los problemas entre figura, representación, decoro y significado teológico). No dejaba de ser osado otorgar un significado con dos intencionalidades bien claras: acreditar y datar el acontecimiento del milagro, abonando a la doctrina de la Inmaculada, y satisfacer la devoción mediante la piedad de los asombros (develando un misterio más de los que encerraba tan incorruptible e inexplicable pintura).

En los pareceres de sus colegas, don José de Alzíbar hizo eco de este hallazgo, sin duda emocionado, apuntaló las deducciones de su maestro al declarar en tono justificativo: "He visto en los ocho parágrafos ocho maravillas, y en el conjunto de todos la octava, por lo que infiero, que en el número ocho, que vuestra merced reflejó en Nuestra Señora, y nos mostró en dicho día, fue anticipado índice de su bien pensada idea". ${ }^{3}$ Nótese el último elogio como otro indicador de que Cabrera, aspirando al papel de un "pintor cristiano" ya discurría y meditaba a priori, no sólo el descubrimiento, sino la asignación de los significados del ocho.

La popularidad con que corrió este hallazgo no se hizo esperar y en verdad causó conmoción en el ánimo de la gente culta y llana. Desde luego que los poetas aplaudieron la revelación de Cabrera, cada vez que repasaban los atributos de la imagen en sus descripciones asonetadas —así vieron en el ocho un autógrafo virginal - y al cabo tomaron partido:

Nunca este número ocho denotara, Como ha solido creer gente sencilla, Ser la Imagen la octava maravilla Cuando es primera y única por rara; Yo pienso que mejor descifrara — y es especie bien obvia que se trilla— Con decir que su Autora, en esa orilla, La Concepción en cifra se firmara. ${ }^{4}$

3. Cabrera, Maravilla americana, 35 .

4. José Antonio Peñalosa, Flor y canto de poesia guadalupana, siglo XIX (México: Jus, 1985), 69. 
Ya que otro poeta había dicho antes:

Tiene un número 8 en su vestido

Y aquel Octavo Número que brilla

Sumando luces entre estrellas tanta,

Octava se acredita Maravilla. ${ }^{5}$

En uno de sus ensayos provocadores, Georges Didi-Huberman replanteó algunas de las bases epistemológicas de la historia del arte o, si se quiere, una simple paradoja en sus operaciones para fijar su objeto de estudio: "La historia de las imágenes es una historia de objetos temporalmente impuros, complejos, sobredeterminados. Es una historia de objetos policrónicos, de objetos heterocrónicos o anacrónicos." ${ }^{\prime} \mathrm{La}$ imagen no sólo deviene inestable en el espacio, por sus desplazamientos inexorables, sino igualmente en los vectores del tiempo y esto no es precisamente una "fatalidad" o limitación en el conocimiento sino una razón de su peculiar "fecundidad". Estamos siempre atentos, pero igualmente rebasados ante la expectativa de un nuevo montaje: "La imagen a menudo tiene más de memoria y más de porvenir que el ser que la mira". ${ }^{7}$ Aunque, en el plano de su transitoria historicidad, no todas las imágenes gozan de esa potencialidad y la inmensa mayoría permanece en estado de latencia o baja densidad; por el contrario, los privilegios de una imagen sagrada en activo radican en que se mueve por igual en los planos de lo expuesto y de lo oculto.

En este artículo pongo a consideración no sólo el problema de la metamorfosis del significado operado en el contexto de la imagen sagrada sino la posibilidad de comprobar que también en los modos de mirar, desde la visión del espectador y sus expectativas epocales, se sucede la mejor parte de su polivalencia y que por esa "anomalía", a la postre, se enriquece la biografía cultural del objeto. Así, desde un signo equívoco o una materia ajena añadida a la imagen (por voluntad o accidente), sucede por la casualidad, la imaginación, la ambivalencia y, sobre todo, el papel del Padre Tiempo metido a pintor, la reescritura de un nuevo capítulo en la historia de la obra. Tanto o más importante es

5. Peñalosa, Flor y canto de poesía guadalupana, 45-46.

6. Georges Didi-Huberman, Ante el tiempo. Historia del arte y anacronismo de las imágenes, trad. y nota preliminar de Antonio Oviedo (Buenos Aires: Adriana Hidalgo, 20II), 32 y 43.

7. Didi-Huberman, Ante el tiempo, 43. 
la trayectoria de "la vida de las imágenes" que el hecho de desentrañar (es un decir) el origen sobrenatural o el estatuto prototípico de una imagen sagrada. En este caso asistimos a la generación ad hoc de una imagen dentro de otra, merced a una visión espontánea, configurada por ocasión, fortuna o simple coincidencia. Una imagen que quedó acreditada por la mirada del agente que la descubrió, complementando su mensaje y expandiendo el campo del contenido. Una imagen potenciada y emergente por efecto de la percepción o la similitud morfológica, según Dario Gamboni, que desata nuevas asociaciones en la memoria, incrustada en otra imagen y sorpresivamente resemantizada por efecto de la manipulación personal o la sugestión colectiva. ${ }^{8}$ Por obra del azar, la mente traduce y produce "imitaciones" por un mecanismo análogo al que se establece entre la semejanza y la cosa: una proyección. Por eso, en el plano de la aprehensión visual, decía Ernst Gombrich, "la imagen accidental" imitativa ocurre desde la psicología de la percepción o lo que él llamó "la aportación del espectador" que no se desempeña siempre como un receptor paciente:

Lo que leemos en esas formas accidentales depende de nuestra capacidad de reconocer en ellas cosas o imágenes que nos encontramos almacenadas en la mente. El interpretar una mancha así como, pongamos por caso, un murciélago o una mariposa, supone algún acto de clasificación perceptiva: en el sistema archivador de mi mente lo pongo en la carpeta de las mariposas que he visto o he soñado. ${ }^{9}$

Entre las imágenes espontáneas y las accidentales hay también las "manifestadas", pero no descifrables al común, que reservan sus códigos o permanecen envueltas en un halo de misterio. Antes que imágenes completas o explícitas son primero un conjunto de signos y su potencialidad depende precisamente en asociarlos para que se reconstituyan en mensaje intencionado: un escopo o blanco de atención general. Es obvio que los signos que derivan de una hierofanía van más allá de los sentidos o los procesos neurológicos, pero es indudable que para ser transmisible el mensaje del numen tiene que atender las reglas del lenguaje y a la postre la concreción de un objeto. Según las categorías sis-

8. Dario Gamboni, Potential Images: Ambiguity and Indeterminacy in Modern Art (Londres: Reaktion, 2002); Dario Gamboni, "The Underground and the Virgin of Guadalupe: Contexts for the Virgen del Metro, Mexico City, 1997-2007”, Anales del Instituto de Investigaciones Estéticas XXXI, núm. 95 (2009): II9-I53.

9. Ernst H. Gombrich, Arte e ilusión. Estudios sobre la psicología de la representación pictórica, trad. Gabriel Ferrater (Madrid: Debate, 1997), I54-I55. 
tematizadas y clasificadas por William Christian, la narrativa de las "apariciones" está basada en signos encriptados, pero ineludiblemente éstos terminan materializándose en objetos concretos que llamamos imágenes sagradas:

Que abarcan los signos (signum, señal), esto es, fenómenos que pueden ser verificados de un modo independiente por los sentidos. Pueden ser vistos por cualquiera que mire y percibidos por cualquiera que toque. La mayor parte de las apariciones tardomedievales están "confirmadas" por signos. Y en la España de comienzos de la época moderna, los signos, sin visiones, llegan a ser la principal atracción. ${ }^{10}$

O en términos más antropológicos "objetos numinosos", según Rudolph Otto, algo que está "fuera de mí", pero vivencial como "presencia" autorrevelada: "Esas manifestaciones de hecho como esas apariciones de lo sagrado en una autorrevelación palpable, son llamadas por el lenguaje religioso: 'signos' ". ${ }^{I I} \mathrm{La}$ exégesis figural entre la Escritura y la cultura de los prodigios alentó una nueva literatura regional panegírica, más aún, generó una afición, peculiar de los confesores y escritores de florilegios marianos, que estaban al acecho de un jeroglífico, latente o encriptado, como aquí, reservado desde su origen para verificar constantemente el milagro y sobre todo mantener "continuada" la trascendencia de su mensaje.

Como se sabe, la imagen de la Virgen mexicana comparte uno de los estatutos más elevados entre las imágenes veneradas por la cristiandad, tan sólo equiparable a la sindone de Turín; no obstante como objeto y materia, o para el ojo escéptico, es un conglomerado de fibras naturales y colores minerales, vegetales y animales. La paradoja es que, ahora mismo, todavía se mantiene potenciada, no ha perdido su aura de sacralidad, vive y se mantiene de esa cultura de los prodigios, se cree que aún reserva a sus devotos arcanos insospechados, entre el misterio y la revelación, o como desde antiguo, cimentada en un discurso simbólico situado entre el mito y la profecía. Un discurso, en suma, de significados poliédricos aplicados por el exceso de devoción y que se mantienen en la mentalidad social, tal como el tópico más difundido y fundante de todos ellos: que se halla estampada por el zumo de las flores "transubstanciadas" y que posibilitaron su hechura acheropoieta o sin intervención de la mano del hombre. De

IO. William Christian, Apariciones en Castilla y Cataluña, siglos XIV-XVI, trad. Eloy Fuente (Madrid: Nerea, 1990), 20.

II. Rudolph Otto, Lo sagrado, trad. Eduardo García (Buenos Aires: Claridad, 2008), I65. 
hecho, la naturaleza de los pigmentos de flores llamó la atención de pintores y científicos desde la segunda mitad el siglo XVII no sólo por su manejo técnico sino por la rareza de que no se hubieran evaporado o disipado. Como se verá, las flores eran un referente real o simbólico determinado por la voluntad de la Virgen, pero problemático a los ojos de la ciencia y el arte, aún conforme avanzaba el Siglo de las Luces. Reales o fingidas, las flores todavía revelan la persistencia de un arcaísmo y reconfiguran, en el discurso y la promoción del culto, distintas nociones del tiempo que coexisten en el imaginario o transmiten una idea del tiempo ancestral que anida y queda atrapado en las imágenes sagradas.

\section{Entre el examen y el dictamen}

Bien se sabe que el texto de Cabrera alcanzó el estatus de autoridad entre los guadalupanistas de los siglos XVIII, XIX y xx y que su popularidad radicaba en que este "príncipe de los pintores" o "Miguel Ángel americano" suscribía sus consideraciones negando a toda "humana industria" la posibilidad de su hechura: no había aparejo, no se reconocía el arrastre del pincel, la mixtura de sus cuatro técnicas pictóricas era nunca vista y ahora ese ocho, que pudiera pasar como un defecto, aparecía como clave de toda la imagen revelada. Pero salvo las fibras del soporte, los ligamentos aceitosos y la hoja de oro hay que notar que Cabrera eludió referirse al origen mismo de los pigmentos, a lo más que llegó fue decir que la saturación del oro en las plecas del manto y los rayos se semejaba al polvillo de las "alas de una mariposa".

La posibilidad de que llegara a mencionar su origen evidentemente mineral y no orgánico pudiera acarrearle una contradicción difícil de zanjar, dada la tradición milagrosa, pues era un hecho aceptado que las especies de la imprimación fueron las flores, señaladamente rosas de Castilla, las que suministraron la materia para colorear e iluminar la imagen. En aras de evitar suspicacias o escándalos, pienso, lo mejor para Cabrera fue no ocuparse del asunto o silenciar este tipo de análisis. Ni por asomo se puede leer una inferencia sobre la naturaleza de los pigmentos, lo cual es más llamativo, ya que desde i648 un sinfín de teólogos y oradores habían dado a las flores del milagro un estatuto semejante a las especies transubstanciadas de la Eucaristía. ¿Cómo hacer evidente, pues, si lo supo, que allí había hollín de ocote, grana cochinilla, carboncillo, cola, verde azul maya de malaquita, entre otros? 
Cabrera, al tiempo que callaba, reportaba un hallazgo en cifra y suma. En su calidad de maestro de la pintura se permitía suscribir esta breve exégesis aunque ciertamente sin tener licencias para ello. Lo hizo no sólo amparado en su piedad personal sino muy posiblemente acreditado por su posición de profesor o facultativo de un arte noble y respetable (semejante al de sus compañeros del protomedicato que otrora habían dictaminado sobre la imagen). Sin embargo, todo hubiera quedado como uno de sus tantos favores sumados a la causa guadalupana si no fuera porque en I820 se publicó otro opúsculo, inédito hasta entonces, del historiador angelopolitano Mariano Fernández de Echeverría y Veytia que reveló las verdaderas condiciones del análisis. Este autor también fue testigo presencial de la inspección en I75I y dejó un testimonio de primera mano, el cual, sorprendentemente, atribuía para sí la paternidad del hallazgo del ocho:

Últimamente después de hechas estas especulaciones muy despacio, hallé otra particularidad, hasta ahora no advertida en otro alguno, y es, que al lado derecho, poco más debajo de la rodilla, tiene en la túnica un número ocho perfectamente figurado. Como si fuese hecho con tinta y pluma gruesa, cuya particularidad hice advertir al señor Abad y a los pintores, que todos la vieron, y convinieron éstos unánimes en que era misterioso, porque a nada contribuye en la pintura. ${ }^{12}$

Echeverría concluyó su obra hacia I775, por lo cual se infiere que retuvo la información más de veinte años. La corrección es de creerse y fue discreta, sin reclamar a Cabrera la paternidad del hallazgo, propia de un hombre elegante y erudito, historiador del México antiguo y viajero por Europa, amigo personal del cronista de Indias Lorenzo Boturini y seguidor, junto con él, de la teoría de la historia de Juan Bautista Vico. En su manuscrito no se trasluce ningún desmentido a lo dicho por Cabrera, pero a diferencia de los silencios del pintor, Echeverría y Veytia volvía a abrir el expediente de los colores para afirmar, como se hizo desde 1666, que la materia de la pintura sí estaba compuesta de flores y que sus pigmentos, semejantes a una acuarela o tinte natural, se habían corrido o transmigrado al envés de la manta, dejando perfilada otra imagen pro-

I2. Mariano Fernández de Echeverría y Veytia, "Baluartes de México. Descripción de las cuatro milagrosas imágenes de Nuestra Señora que se veneran en la muy noble, leal e imperial Ciudad de México, capital de la Nueva España, a los cuatro vientos principales, en sus extramuros, y de sus magníficos santuarios, con otras particularidades" [1820], Testimonios históricos guadalupanos, compilación, prólogo, notas e índices de Ernesto de la Torre Villar y Ramiro Navarro de Anda (México: Fondo de Cultura Económica, 1982), 55I [las cursivas son mías]. 
piamente labrada con flores (como se ha mirado tan pocas veces y hasta hace un lustro jamás reproducida) (fig. 4). ${ }^{13}$ Había, pues, dos imágenes elocuentes para corroborar el milagro: la del haz nítida y con el diseño armonioso y la del anverso propiamente estampada o mojada por los jugos de las flores. Ya el padre Francisco de Florencia, en el contexto de las informaciones de I666, se había conmovido al detectar la imagen del envés, y para su fuero interno, allí radicaba la sustancia física del milagro (como se verá). Ésta fue la verdadera recontribución de Echeverría y Veytia, ya que en efecto pudo ver la tilma del indio por detrás, levantándola de su bastidor, junto a los pintores examinadores y el abad. Lo dijo basado en la referencia documental de i666 cuando tuvo lugar el primer examen por los artistas de entonces:

Quedó en ella pintada la Santa Imagen, y por la otra parte dibujadas las flores. Con esta noticia, cuando logré la dicha de ver y tocar el sagrado lienzo fui con gran cuidado y curiosidad a reconocer ésta: mas no hallé otra cosa que las que dejo referido y me ha parecido conveniente [que hay otra imagen por detrás] declararlo así en obsequio de la verdad.

Y a renglón seguido dejaba a los investigadores de la posteridad la emocionante ¿̇o escéptica? tarea de averiguarlo: "Puede que [desde] aquellos tiempos [de I666] se manifestase este otro prodigio, que ahora ha cesado, así como ahora se ha descubierto el número ocho del que hablé arriba que nunca se había

I3. Luego de la inspección y del proceso de conservación realizados en 1982, de lo que se hablará más adelante, se tomó el acuerdo institucional de nunca dar a conocer las tomas fotográficas que se hicieron al envés de la imagen de la Virgen, a solicitud del entonces abad Guillermo Schulenburg Prado y con toda la discreción que se aconsejaba entonces. Dada la iniciativa y diligencia del que era director del Museo de la Basílica de Guadalupe, todos estos materiales quedaron resguardados en una bóveda de seguridad para no suscitar equívocas interpretaciones o provocar el mal uso de estos materiales. Sin embargo, al parecer de manera unilateral y subrepticia, el presbítero Eduardo Chávez ha exhibido recientemente en repetidas ocasiones la vista de la "Virgen de las flores". Una copia de la diapositiva se la suministró el propio padre Chávez al físico Adolfo Orozco, quien la publicó, quizá por primera vez y, por tanto, aquí mismo la presentamos no como obra artística o de culto sino como simple documento testimonial, ya que ahora es del dominio público. El lector disculpará la mala calidad de la reproducción, puesto que no hay acceso a ningún otro recurso visual. Pero también entenderá las disquisiciones que sobre esta otra imagen hicieron el padre Francisco de Florencia, el historiador Mariano Fernández de Echeverría y Veytia y el restaurador José Sol Rosales. Adolfo Orozco, "Curiosidades científicas guadalupanas", Voces. Diálogo misionero contemporáneo. Actas Bienales del Colegio de Estudios Guadalupanos, primera parte, año I, Arturo Rocha, ed. (México: Universidad Intercontinental-Escuela de Teología, 20I4), 25-6I. 
4. Imagen del envés de la Virgen de Guadalupe, tomada de Orozco, "Curiosidades científicas guadalupanas" (vid supra n. I3). (C)Foto: Emeterio Guadarrama.

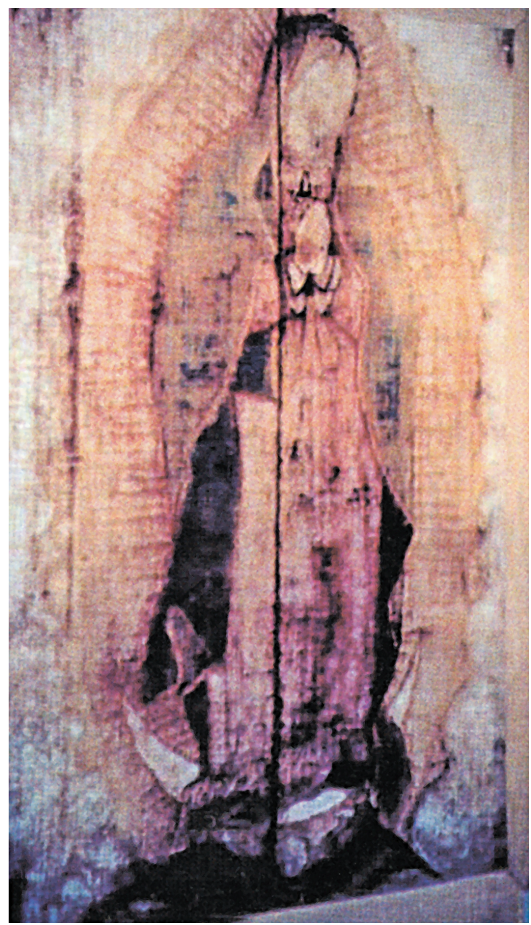

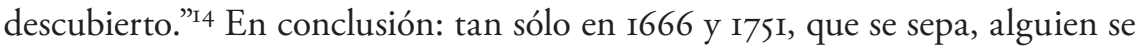
pudo asomar al reverso y sólo unos cuantos han podido contemplar la imagen gemela, compuesta de manchones, pero tenida como la más legítima para probar la estampación por zumo de rosas, que habría teñido e impregnado las toscas fibras de la tilma. ${ }^{I 5}$ Una imagen que, como hemos dicho, hasta hace poco

I4. Fernández de Echeverría y Veytia, "Baluartes de México", 553.

15. En efecto, los pintores de la inspección de i666 fueron los primeros sorprendidos con el hallazgo del envés y así lo dejaron jurado: "Y advertimos y notamos que toda la Santísima Virgen se ve distintamente pintada por el envés del lienzo, y de la misma manera los colores en que se reconoce evidentemente que no tiene aparejo alguno, ni imprimación el dicho lienzo más que el cuerpo que los mismos colores le dieron, tupidas e incorporadas con los hilos toscos del otro lienzo. Y concluyeron que lo que llevan declarado lo sienten así conforme a su arte de pintar, y mayor abundamiento el dicho licenciado Salguero lo juró in verbo sacerdotis, puesta la mano en el pecho y los demás a Dios y a la cruz en debida forma de derecho". Eduardo Chávez Sánchez, La Virgen de Guadalupe y Juan Diego en las Informaciones jurídicas de I666, colaboraciones de Alfonso Alcalá, 
DOI: http://dx.doi.org/10.22201/iie.18703062e.2017.1.2593.

I7O

JAIME CUADRIELLO

permanecía "cesada" y ahora ha empezado a circular de manera imprudente, ya que sin estudios matéricos formales y consistentes, no sabremos si se usará para abonar o descalificar el tradicional prodigio de la pintura.

La disyuntiva entre la procedencia mineral o vegetal de los pigmentos, o incluso que fueran procesados, como se aprecia, no era un escollo menor para los apologistas y hasta la fecha es una pregunta que sigue en el aire o guardada bajo llave. Bien lo advirtió el jesuita Francisco de Florencia, que aunque pudo o no estar en la inspección de I666, sí confesaba haber contemplado junto con el canónigo Francisco de Siles el Sagrado Original por el envés y haber palpado sus manchones de tintura orgánica. Desde luego era difícil desmentir las aseveraciones del jesuita, sobre todo ponderada esa imagen tan anómala que era prueba patente de que se trataba de "un milagro continuado" estampado en flores:

Este día puse atención en el revés de la sagrada pintura y se la ayudé a poner al dicho don Francisco de Siles, que fue quien me la hizo mostrar y a otros, y todos convenimos en que en lugar de la imagen que había de salir en sombra, por ser tan rala la manta, lo que se veía eran unos manchones de colores, como del jugo exprimido de varias flores y hojas de ellas, de suerte que nos parecía que se distinguía el verde oscuro de las hojas de la azucena, el blanco nevado de ella, lo morado del lirio, lo sonrosado de la rosa, lo azul de la violeta, lo amarillo de la retama, mezclados los uno y otros con distinción y separados con una inconfusa mixtura en que estuvimos algún rato admirándonos y notándolo, señalando en los colores cuál era de esta rosa y qué de aquella. ${ }^{16}$

Esa contraimagen marial resguardada a la vista y reservada para la calidad de un nuevo aprecio, se ha divulgado ilusamente luego de 350 ańos, vulnerando el celo de generaciones, el decoro de las autoridades, la tradición de sus custo-

Raúl Soto Vázquez, José Luis Guerrero Rosado y Peter Gumpel (México: Insigne y Nacional Basílica de Guadalupe, 2002), 412-4I3.

I6. Francisco de Florencia, Estrella del norte de México, aparecida al rayar el día de la luz evangélica en este Nuevo Mundo, en la cumbre de el cerro de Tepeyacac orilla del mar Tezcucano, a un natural recién convertido, pintada tres días después milagrosamente en su tilma, o capa de lienzo, delante del obispo $y$ de su familia en su casa obispal. Para luz en la fe a los indios, para rumbo cierto a los españoles en la virtud, para serenidad de las tempestuosas inundaciones de la laguna. En la Historia de la milagrosa Imagen de Nuestra Señora de Guadalupe de México, que se apareció en la manta de Juan Diego (México: imprenta de doña María de Benavides, viuda de Juan de Ribera, I688), I39v-I40r. Florencia afirma que vio la imagen del envés, no es enfático si en la inspección de 1666 o en otra ocasión inmediata. 
dios y el estatuto tan elevado de una imagen sagrada, paradójicamente la que se cree la más sagrada de la cristiandad.

\section{Copias auténticas, facsimiles imposibles}

A partir de I75I, los subsecuentes "verdaderos retratos" salidos del taller de Cabrera y de sus coetáneos no sólo llevaban un colorido distinto, más vivaz y menos terroso, gracias a los registros de las templas, sino el distintivo de esa nueva cifra recostada o ese número ocho que los identifica y los signa, literalmente, como auténticos facsímiles y con apego a los detalles. Esto además data las copias en un tiempo real y ancestral, merced a las interpretaciones de una fecha de origen celestial. De tal manera, los historiadores del arte actuales, metidos a la práctica del expertise, hemos podido fechar las copias posteriores a I75I con mayor precisión. Ya que, ciertamente, ni Juan Correa, ni los hermanos Rodríguez Juárez emplearon semejante cifra e incluso para otros artistas, ajenos a la interpretación de Cabrera, no dejaría de ser un manchón que afearía el conjunto de la obra. O en palabras de Echeverría: "Porque a nada contribuye a la pintura". Ahora mismo conozco a varios restauradores que, igualmente ignorantes de esta tradición de fidelidad y piedad, borran o recubren el ocho para quitar, paradójicamente, su mejor certificado de autentificación y que proclamaba desde entonces que se trataba de una "copia en todo sacada del original".

Tampoco deja de sorpender la forma tan temprana y eficaz como se divulgó este descubrimiento, incluso del otro lado del Atlántico. Ya en 1754, en Ausburgo, los afamados hermanos Klauber abrían una gran lámina para celebrar el reconocimiento pontificio del papa Benedicto XIV al patronato de la Virgen sobre el reino de la Nueva España, a pedido, desde Roma, del procurador jesuita de la Nueva España. En tan exquisita y complicada alegoría, uno de los mejores ejemplos del gusto rococó de esa escuela de Baviera, se luce un ocho en la túnica de la Guadalupana, apenas tres años después de haber sido reportado por los dictaminadores y dos años antes de publicarse en la prensa el dictamen cabreriano (fig. 5). Es sintomático que el pontífice, con su dedo índice de expresión admonitoria, parece muy complacido en señalar el punto en que está trazada esta cifra y que conoció mediante una fiel copia realizada por el mismo Cabrera. El procurador aseguraba que, a la vista de la imagen, Benedicto XIV despejó todas sus dudas sobre el milagro antes de conceder la bula, el breve y su apotegma respectivo, obsequiado con un sentido de distinción a 
DOI: http://dx.doi.org/10.22201/iie.18703062e.2017.1.2593.

172

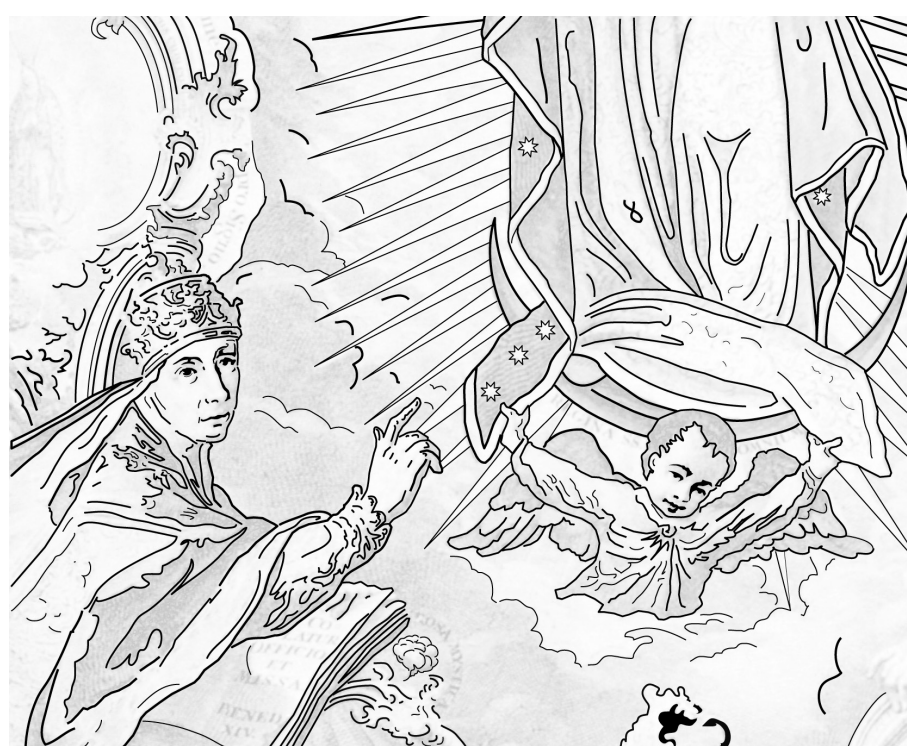

5. Detalle del ocho, ilustración en escala de grises basada en la impresión en papel del grabado en metal: Joseph Sebastian Klauber y Johann Baptist Klauber, grabaron, Alegoría del patronato de la Virgen de Guadalupe sobre la Nueva España, ca. 1754-1758. Colección Museo de la Basílica de Guadalupe, Ciudad de México. Dibujo: Fernando Herrera.

los habitantes de la Nueva España y tomado del libro de los Salmos: non fecit taliter omni natione [No hizo nada igual con ninguna otra nación].

En otro lugar se ha estudiado cómo Cabrera llegó al grado de reinventar una iconografía peculiar, compensatoria y osada: el taller celestial u obrador trinitario. Una escena complaciente en que la personificación del Padre Eterno daba los últimos toques al lienzo antes de ser transportado y comisionado, por los ángeles, al neófito indio Juan Diego (fig. 6). El deus creator et artifex tampoco tenía empacho en suscribir el ocho como data de su propia creación (incluso idea divina del misterio de la Inmaculada antes de que María fuese conocida en cuerpo en Nazaret). Conozco al menos tres casos de este tipo iconográfico en que aparece el ocho en el mismo sitio en que lo detectó el "Miguel Ángel mexicano", y con lo cual, obviamente, el significado concepcionista de estas alegorías se potenciaba. Incluso, la cifra bien podía haber sido escriturada desde el origen de los tiempos, cuando la omnipotencia divina ideó e inventó a esta Segunda Eva sin mancha de pecado y, más tarde en I53I, cuando se hizo realidad en 


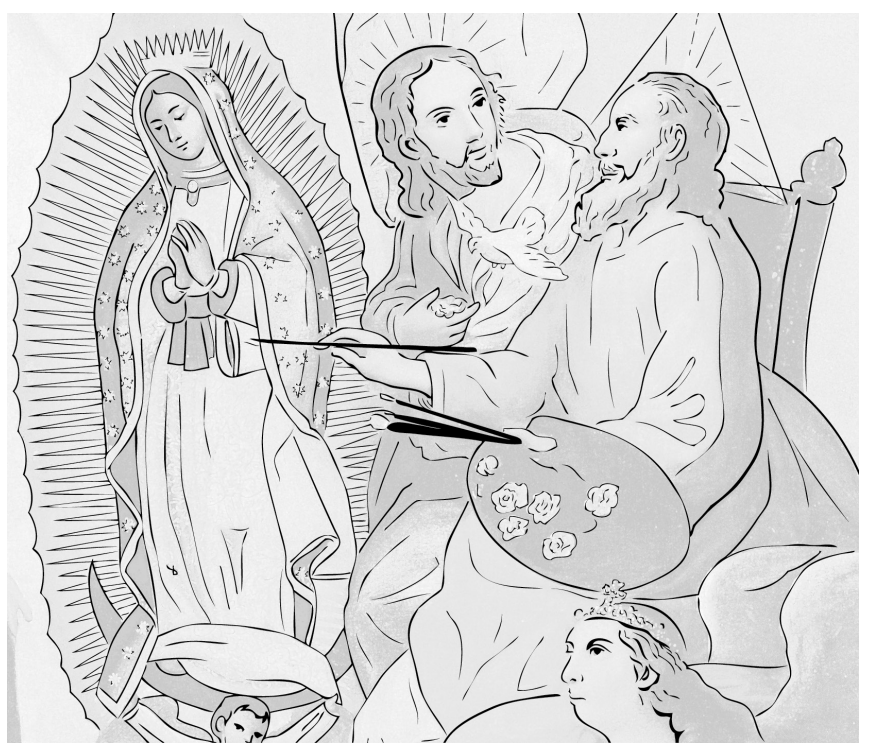

6. Detalle del ocho, ilustración en escala de grises basada en la pintura: Juan Patricio Morlete Ruiz (atribución), El padre eterno pintando a la Virgen de Guadalupe, segunda mitad del siglo xviıI, Colección Museo de la Basílica de Guadalupe, Ciudad de México. Dibujo: Fernando Herrera.

imagen durante su aparición en Guadalupe (por descabellada que parezca era una de las tesis favoritas de los oradores novohispanos).

Merced a las afirmaciones cabrerianas, el ocho incrementaba aún más el tema de lo inefable o la idea de que el Sagrado Original resultaba inimitable a la destreza de los pintores, y que sus copias, por más expertas y meticulosas que fueran, al cabo no lograban producir el mismo efecto de maravillar y conmover, según los presupuestos de la hipotiposis o de la función retórica de hacernos creer que estamos delante de un prototipo en vivo y de visu y no de una imagen de reemplazo o sustitución. Desde mediados del siglo XviI, ya se decía que sólo los pintores indios, hermanos de raza de Juan Diego, tenían el don de trasladar el modelo lo más aproximado a su original. ${ }^{17}$ Los esfuerzos de Cabrera - y de otros pintores más- por copiarla con el registro de las templas y un calco terminaban

17. Elisa Vargaslugo, "El indio que tenía el 'don'”, Anales del Instituto de Investigaciones Estéticas XXVII, núm. 86 (2005): 203-215. 
DOI: http://dx.doi.org/10.22201/iie.18703062e.2017.1.2593.

174

JAIME CUADRIELLO

ofreciendo un pálido remedo y los oradores repetían esto como lugar común. O la consabida expresión de que a todas las copias les "faltaba un no sé qué" para así resolver, por indeterminación, que los sentidos eran incompetentes para apreciar en todo su celestial belleza. Imagen inimitable porque es del cielo, cuan irremplazable por "sin segunda" en la tierra, o porque de plano se halla "sacramentada" por la consagración de las flores. A este discurso ditirámbico y complaciente se subordinaba la teoría de la pintura. Pero no deja de ser paradójico que ya por entonces, luego de que Cabrera suscribiera su casi total "rendición", se dejaran sentir las primeras inquietudes por su paulatino deterioro o posible desaparición (que de alguna manera ya negaban ese estatuto de "lo inefable").

El dictamen cabreriano dejó una larga cauda de admiración y reconocimiento para su autor y se hizo amplio uso de sus facultativos saberes; pero también abrió la puerta a las dudas metódicas del Siglo de las Luces y, desde luego, a una escisión en la sostenida tradición o en la otrora unánime y universal aceptación del milagro. El eminente doctor criollo José Ignacio Bartolache ha sido en la historiografía guadalupana el primer escéptico declarado o quien, al menos, no se pronunció con la contundencia acostumbrada, y desde los recursos de la ciencia moderna - y la experimentación pictórica-, dejó más dudas que respuestas satisfactorias pese a que su opúsculo publicado en 1790 se llamó, paradójicamente, Manifiesto satisfactorio (fue una edición póstuma de un proyecto comenzado en 1786). Con la anuencia del abad realizó tres inspecciones a vidriera abierta, acompañado de un notario y cinco pintores de lo más calificados y cercanos a la Real Academia de San Carlos. La inquietud principal de este médico, astrónomo y matemático de la Real y Pontificia Universidad fue demostrar que el tejido del lienzo no era de fibras de maguey o ixtle, sino de una pita más tersa o palma llamada iczotl (que facilitaría la estampación) y para ello fabricó dos tilmas de cada material, y las hizo pintar sin aparejo "pelo a pelo" para demostrar (lo que finalmente le ganó el enojo de muchos) que por más delgada que fuese, la imagen sí tenía imprimatura o aparejo y que la capa del indio era más suave y receptiva de lo que se pensaba.

En una de las láminas grabadas incluidas en su libro no sólo dio cuenta del dibujo botánico del iczotl, sino que con la frialdad de un científico tomó el calco del número 8, y declaró al pie de ilustración: "Tamaño y figura del rasgo que le pareció al Maestro don Miguel Cabrera ser un misterioso número 8 en Nuestra Santa Imagen Guadalupana” (fig. 7). Para rematar su ninguneo a Cabrera, "preguntó también, ¿qué les parecía del número 8 de que habla don Miguel Cabrera en su Maravilla americana, si es cosa especial o no? 
DOI: http://dx.doi.org/10.22201/iie.18703062e.2017.1.2593.

7. Anónimo novohispano, Iczotl, ca. 1787 , $\mathrm{I} 8.3 \times 13.5 \mathrm{~cm}$, tomado de Bartolache, Manifiesto satisfactorio (vid supra, n. I8), [107].

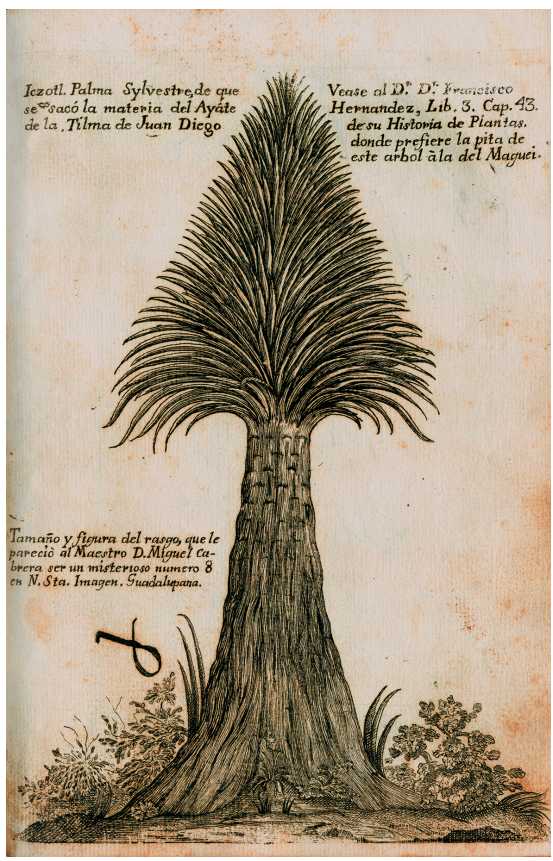

[Los pintores] Respondieron que no es cosa especial, y le copiaron idéntico". ${ }^{18}$ Pregunta consignada en acta notarial del I de marzo de 1787 certificada por Joseph Antonio Morales, escribano de su majestad.

La ciencia de la Ilustración, de un plumazo, redujo a la nimiedad las barrocas elucubraciones de Cabrera, publicadas cuatro décadas atrás, y de alguna manera desacralizó la imagen —o más bien escandalizó a los criollos—, al poner en duda el valor de esa data tan fervorosamente creída y puesta de rigor en las verdaderas copias y que, a petición popular, no podía excusarse. La inclusión del ocho no sólo era para embelesarse en sus secretos, sino para certificar su circulación a plenitud, datar y vincular todavía más la función de la imagen como icono. Llama la atención la difusión de esta práctica no sólo entre los copistas cultos y académicos sino aun entre los populares y periféricos a la

I8. Joseph Ignacio Bartolache, Manifiesto satisfactorio anunciado en la Gazeta de México, t. I, núm. 53, Opúsculo guadalupano (México: imprenta de Felipe Zúñiga y Ontiveros, 1790) [“Apéndice"], 8-9. 
DOI: http://dx.doi.org/10.22201/iie.18703062e.2017.1.2593.

176

JAIME CUADRIELLO
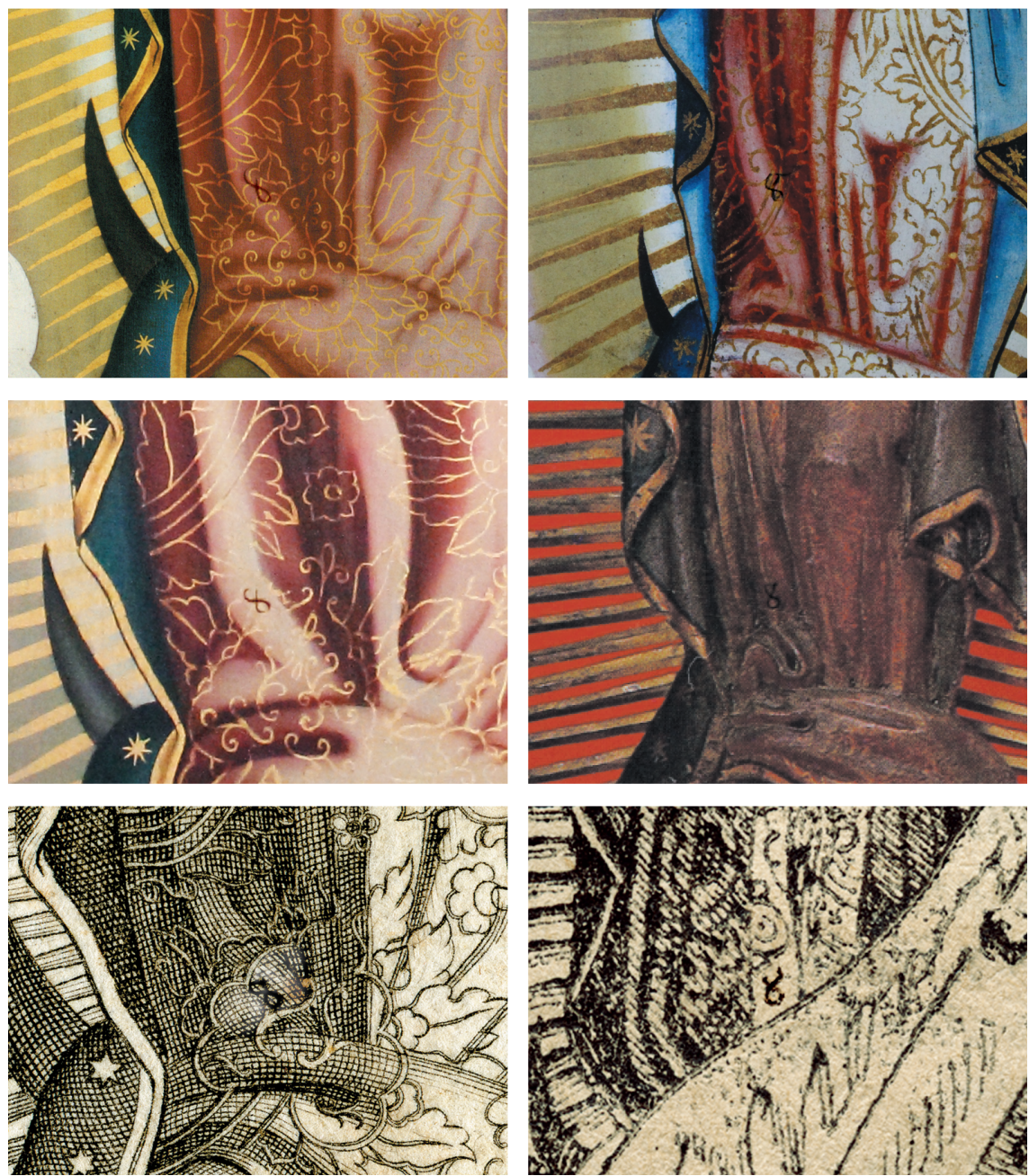

8. Mosaico de detalles con el ocho, tres pinturas, una escultura y dos grabados, nótese que los grabados provienen significativamente de las obras de Bartolache y Posada: a-d) anónimos novohispanos, Virgen de Guadalupe, siglo xviII. Colección particular, Ciudad de México; e) José Guerrero, dibujó, Tomás Suria, grabó, Nuestra Señora de Guadalupe de México. La más semejante a su original, $1790,15.7 \times 10.3 \mathrm{~cm}$, tomado de Bartolache, Manifiesto satisfactorio (vid supra, n. $\mathrm{I} 8$ ); f) José Guadalupe Posada, Coloquio para celebrar las cuatro apariciones de la Virgen de Guadalupe, 1913, I7× IO cm. Colección particular, Ciudad de México. Fotos: Fernando Herrera. 
Ciudad de México; así, el ocho se reprodujo a tal grado que alcanzó rasgos descomunales, desproporcionados o caprichosos (fig. 8). Sin contradicción alguna y para favorecer a su clientela, el ocho estuvo patente en los trabajos de los estrictos directores de la Academia de San Carlos de 178I, e igual en sus antagonistas los artífices de las tiendas de los "tratantes" o imagineros que gustan de confundir esta cifra entre el dorado de los arabescos a modo de un encaje. ${ }^{19}$ Todo, desde luego, quedaba certificado por las inscripciones que dicen contener las medidas exactas, los detalles y, en casos más privilegiados, el hecho de que la copia había sido tocada a su Sagrado Original (estimulando el principio de la inmanencia o de las cadenas de simbolización sacralizada de su prototipo). Incluso en la escultura no es raro hallar este guarismo entre el estofado, también en una forma minúscula en los escudos de profesión de una monja o, todavía más sorprendente, en el pespunteado en los bordados o dechados femeninos. Este hábito entre la devoción y la admiración no decayó entre los artistas de la Academia durante el siglo XIX o los provincianos, lo mismo en la estampa popular de Vanegas Arroyo, como veremos, y hasta un pintor reconocido del muralismo mexicano, como Jorge González Camarena, metido a ilustrador para cromos de calendario, todavía mantenía la costumbre gremial de insertar la cifra hacia la década de 1940 (fig. 9).

\section{Debate numerológico, mitos proféticos}

El fraile Servando Teresa de Mier predicó un sermón en la Colegiata de Guadalupe en diciembre de 1794, en el que aseguraba que la tilma de Juan Diego era nada menos la capa talar del apóstol santo Tomás, un legado de su paso por este continente en el siglo i y la imagen impresa, por tanto, un retrato fiel de María realizado en Éfeso, aún en vida de la misma y antes de su Asunción a los cielos. Ya se sabe que sus audaces tesis iban encaminadas a legitimar

I9. Por paradójico que parezca en la edición póstuma de Bartolache de 1790 está puesto el ocho nítido y resaltado. Se trata de una excelente plancha al aguafuerte, dibujada por José Guererro y grabada por Tomás de Suria que se dice ser "la más semejante a su original" (fig. 8e) con todo y su marco moldurado y martillado, lo cual enfatiza, junto con el ocho, que sus autores quisieron apegarse en todo a la tradición de la vera effigie. Siete años después la misma plancha se reutilizó en la contraportada de: Ignacio Carrillo y Pérez, Pensil americano, florido en el rigor del invierno. La imagen de María Santísima de Guadalupe, aparecida en la corte de la septentrional América México (México: imprenta de don Mariano de Zúniga y Ontiveros, I797). 
la más ancestral antigüedad y el origen apostólico de la imagen y, de paso, a descalificar la causa eficiente de la Conquista y evangelización por obra de Patronato Real. Al acreditar que la llegada de la palabra de Dios y la revelación fue un mandato universal de Jesucristo, que tuvo lugar de manera simultánea en todo el orbe, no sólo cuestionaba la tradición aparicionista de I53I sino que iba más lejos al colocar la imagen del Tepeyac en un estatuto superior a cualquier icono lucano o pintado por el evangelista Lucas: se trataba de un autorretrato. Era obvio que el ilustrado arzobispo de México se escandalizara por estas afirmaciones no sólo por descabelladas sino por su peso mítico y profético. Entonces emprendió la persecución y represión en contra de este locuaz dominico que hasta entonces se había desempeñado como orador consentido en los fastos oficiales. Al predicador se le sometió a un juicio acusado de iluso, escándalo y desacato. Acabó en prisión y una vez confiscados sus papeles se le exilió a España (para quedar incomunicado en una celda de su orden en las montañas de Santander). Escapó cinco veces de sus reclusiones, pasó por Lisboa, París, Roma y Londres, regresó a la Nueva España dos décadas después para avivar e impulsar la guerra de Independencia. Mier fue diputado constituyente y benemérito de la patria, su cuerpo, hallado momificado, se le vendió a un circo y terminó exhibido en un diorama en Buenos Aires en I867. ${ }^{20}$

Entre los argumentos más contundentes para probar sus asertos, acerca del cristianismo antiguo (más allá de las etimologías y la refuncionalización de los mitos indígenas), no dudó en volver sobre el número ocho que identificó, acomodaticiamente, con un signo de la lengua asirio-caldea y, desde luego, como ideograma tomasino. A mitad de su pieza, en el día más solemne de la fiesta guadalupana, así lo espetó para pasmo y sensación de su auditorio:

Y todo esto ya me parece apoya que la imagen de nuestra seńora es pintura de los principios del siglo primero de la Iglesia, aunque su pincel es superior a toda humana industria, como que la misma Virgen María viviendo en carne mortal se estampó naturalmente en el lienzo.

\section{Cuarta proposición:}

Entre las razones que ocurren para probar $[\ldots]$ quiero referir sino las que ministra a nuestros ojos la misma imagen. Veis que sobre el pie derecho a poca distancia tiene

20. Servando Teresa de Mier, Obras completas. I. El heterodoxo guadalupano, estudio y selección de Edmundo O’Gorman (México: Universidad Nacional Autónoma de México, 198I). 


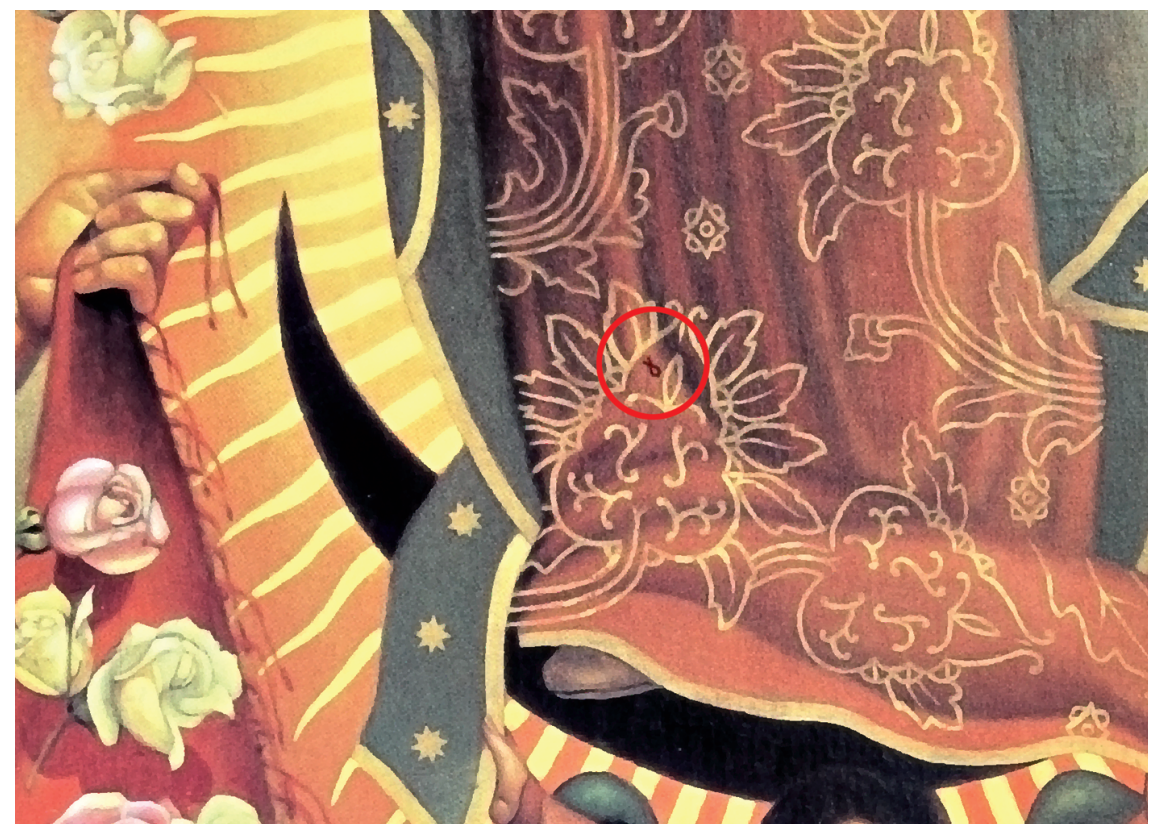

9. Detalle del ocho en Jorge González Camarena, Milagro del Tepeyac, I947, $200 \times 163 \mathrm{~cm}$. Colección Galas de México, Ciudad de México. Cortesía Museo Soumaya. D.R. Jorge González Camarena/somaAp/México/20I7.

uno que ha parecido número 8, aunque por estar abierta una de sus esferas figura mejor una tenaza. El piadoso pintor Cabrera lo discurre misterioso y que o nos recuerda que apareció en la infraoctava de su Concepción o que es su pintura la octava maravilla. Bartolache con sus pintores afirma por el contrario, que no es cosa especial [la primera versión dice: "que no es cosa especial, sino, tal vez, un rasgo residuo de mano atrevida” (nota de Edmundo O’Gorman)] ¡Ah, uno y otro se engańan! Es una letra o carácter sirio-caldeo, idioma nativo en que hablaban y escribían los apóstoles. Luego la imagen es del tiempo de Santo Tomás, y lo particular sobre el asunto es que tengo el mismo carácter escrito dos veces en la orla de caracteres sirio-caldeos que tiene la cruz impresa en mármol con sangre de Santo Tomás, y descubierta en la ermita donde oraba cerca de Meliapor [en la India], antigua corte de Coromandel, donde se halló su cuerpo; ¡cosa de notar! Al mismo tiempo que acá se concluyó la conquista que tan puntualmente predijo. Tales caracteres de aquella cruz estuvieron como exóticos ignorados veintinueve años, hasta que fueron interpretados a solicitud del obispo 
de Cochin, y remitida la interpretación al rey don Sebastián, la aprobó de comisión especial de la Silla Apostólica el infante cardenal don Enrique arzobispo de Lisboa. Ojalá, ilustrísimo señor [se dirige al arzobispo de México allí presente], que vuestra excelencia también, pues posee ese idioma, reflejando en ese carácter, nos sacara de dudas con su interpretación. Yo no la atino, ingenuamente, ni por cotejo con los otros caracteres de la cruz, porque este idioma contiene muchas cláusula en una sola letra, y aun en solas cuatro está toda la salutación angélica, con la que, traducida del mismo sirio-caldeo concluiré yo mi sermón en memoria a nuestra Señora de las muchas veces que se la rezaría su santo apóstol Tomás. ${ }^{21}$

Estas argumentaciones eran todo un desafío que, de frente e in situ, lanzaba fray Servando al arzobispo Núnez de Haro. O casi una provocación ya que interpelaba a su erudición en lenguas y arte glífica y, sin duda, esta manera de retarlo pudo ser el momento de mayor irritación para Su Ilustrísima. Al cabo, motivo de incomodidad y venganza: el proceso en su contra resultó fulminante y humillante para el predicador, una verdadera persecución pues vivió más de una década a salto de mata. Bien visto, situado entre el desafío de un criollo en contra de los peninsulares, un desplante de insolencia y desvarío en agravio de las mentes ilustradas. A través de este pasaje, nada inocente o cándido para las estrategias del fraile decidido a atacar a los gachupines, se dejaba ver la manera tan coercitiva con que quiso involucrar al arzobispo (autoridad que validara sus pesquisas), para ganar, así, el beneplácito diocesano. Entre las líneas de este sermón también se notan las tensiones y enojos que dejaron las conclusiones escépticas del doctor Bartolache y una red de intereses criollistas. La averiguación demostró que detrás de esta pieza estaba un anticuario y experto en jeroglíficos mexicanos: el licenciado Ignacio Borunda, que asesoró al fraile. Ambos apostaron por usar un expediente mítico y críptico que era una respuesta casi desesperada por salvar el honor de la imagen y llevar agua al molino propio de su condición cultural o restañar un orgullo local atacado por el jansenismo, la ciencia y el ataque ilustrado a las creencias.

De hecho, este lance demuestra que el asunto del ocho ya se había vuelto un exceso incómodo para la mentalidad cambiante de la Ilustración: de ser posiblemente un indicio viquiano y universalista según el escrutinio de Echeverría, había pasado a condición de engañifa maliciosa. Sin embargo, fray Servando todavía en sus cartas al cronista real de Indias, Juan Bautista Muñoz,

2I. Teresa de Mier, Obras completas, t. I, 249. 
Io. Detalle del ocho en $\mathrm{La}$ cruz milagrosa del apóstol Santo Tomás en Madrás (Maliapor), India, $30 \times 20.5 \mathrm{~cm}$, en Atanasio

Kircher, La Chine d'Athanase Kircher de la Compagnie de Jesus: illustrée de plusieurs monuments tant sacrés que profanes et de quantité de recherchés de la natura et de l'art, trad. FrançoisSavinien d'Alquie (Ámsterdam: Johannem Jansonium \& Elizeum Weyerstraet, 1670) [encarte entre las páginas 74 y 75$]$. Colección particular, Ciudad de México.

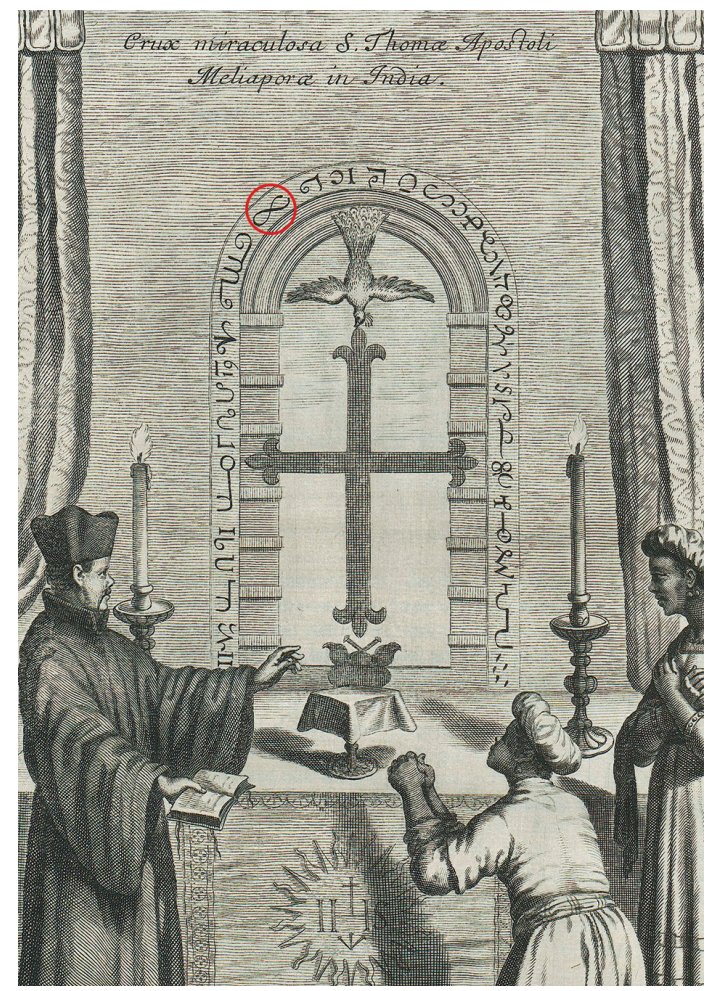

reivindicaba su prestigio intelectual y, aunque ya negaba la aparición guadalupana de I53I, en cambio, seguía sosteniendo su tesis sobre la predicación antigua de santo Tomás y el número ocho volvió a ser un argumento validado. En esa ocasión reveló cuáles habían sido sus apoyaturas documentales: el anticuario jesuita Athanasius Kircher y el cronista agustino Antonio de la Calancha. Volvió a insistir en las evidencias glíficas de la cruz de Meliapor, reportada por los jesuitas de la India y bien conocidas gracias al grabado de Kircher, pero también quedaba claro que, por los consejos de Borunda, descifraba un grabadito tomado de la crónica peruntina de De la Calancha, que mostraba las huellas del apóstol, y era la mejor prueba para validar sus asertos (fig. Io):

Dije en el sermón que tal vez haría al caso de la proposición que estoy probando, el famoso número 8 que la imagen tiene al pie. Ello puede ser una casualidad; pero también puede ser alguna cifra o resto de un letrero siro-caldeo, porque sin duda ni 
I82

es número 8, como lo llaman, sino un carácter de dicha lengua, que se ve en la orla de la célebre cruz de Santo Tomé en Meliapor, explicada de orden del cardenal D. Enrique, infante de Portugal. El mismísimo se halla en la famosa piedra excavada en China, relativa a la predicación de san Bartolomé en el siglo séptimo, explicada en Roma por el padre Kircher. De esta misma lengua parecen ser las inscripciones grabadas sobre piedras, que se hallaron en ambas Américas, con tradición de ser relativas a la predicación de Santo Tomé [...] El P. Calancha grabó una [...] Estas cosas debieran haber merecido y merecer más atención, que las de alborotar al populacho ignorante. ${ }^{22}$

Nótese que Mier ahora introduce el factor de "la casualidad" en la hechura del ocho guadalupano, pero no deja de aferrase a la lectura que De la Calancha había hecho de uno de los famosos petroglifos del pueblo de Calango, al sur de Lima, y esa huella del pie tomasino estaba certificada por unos caracteres que el mismo apóstol "pintó con el dedo, unas griegas y otras hebreas". En el calco de esa losa, borrada por un visitador del arzobispo de Lima para prevenir idolatrías, se declaraba como "piedra donde se paró la estrella" (anunciando el Tepeyac de México) y en las XX unidas estaba la reiteración de ese mismo ocho (que dejaba de serlo como guarismo arábigo) pero que era el ideograma del nombre del apóstol dubitativo y predicador andariego. Queda claro que entre los desplantes de un erudito a la violeta y la incomprensión de la jerarquía, "el populacho" seguía ajeno a las disputas de los letrados y sus territorios de poder (fig. II). ${ }^{23}$

\section{Figuras espontáneas, materia accidental}

La más fuerte reprimenda a Bartolache, aunque póstuma, corrió a cargo del canónigo cubano Francisco Xavier Conde y Oquendo. En 1796 escribió en dos tomos una obra apologética, tan obsesiva como incriminatoria, para responder al breve opúsculo del matemático universitario. Nótese el tono y el destinatario de sus palabras: quien por su "osadía y descaro" y "falsedad desfachatada",

22. Servando Teresa de Mier, Obras completas. III. El heterodoxo guadalupano, estudio y selección de Edmundo O’Gorman (México: Universidad Nacional Autónoma de México, I98I), 2 II.

23. Antonio de la Calancha, Crónica moralizada del Orden de San Agustín en el Perú, ed. Ignacio Prado Pastor, t. II (Lima: Universidad Nacional Mayor de San Marcos, 1974), 739-743. 
DOI: http://dx.doi.org/10.22201/iie.18703062e.2017.1.2593.

II. "Dibujo de la coyor sayana que quiere decir piedra donde se parava la estrella", en De la Calancha, Crónica moralizada (vid supra n. 23), 742.

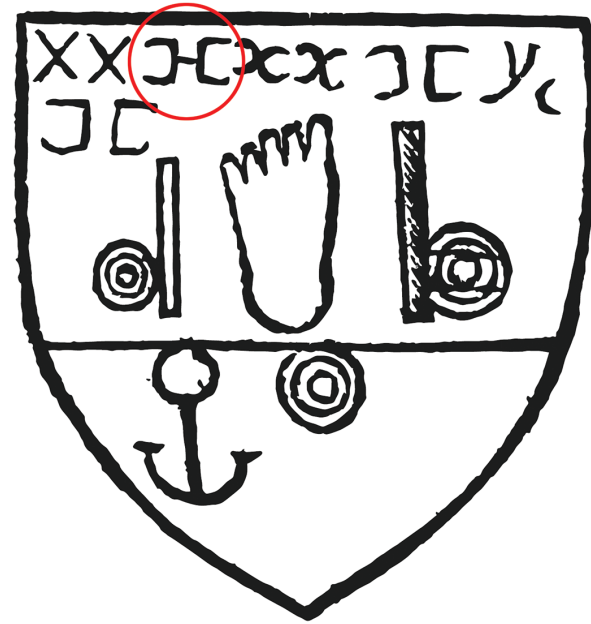

intentaba "deslucir la pintura y desmentir a Cabrera, cara a cara y en público". ${ }^{24}$ En esta empresa de restitución se auxilió de un discípulo sobreviviente de Cabrera, el maestro José de Alzíbar, quien no por casualidad quedó excluido de la "pandilla" o "turbamulta" de artistas convocados por Bartolache, obviamente porque iría predispuesto como juez y parte desde su anterior conformidad, dada en el dictamen de I75I. Esta nueva colaboración entre autor y pintor "decano" era para exculpar al difunto Cabrera de la interpretación hecha del ocho mediante el recurso de maximizar los errores del contrario, minimizando el desliz de Cabrera: "El Dr. Bartolache que con varios escribanos al lado, se iba a cada rato al Santuario y andaba buscando menudencias ridículas en que ocupar la fe pública, como es aquel rasgo tirado por el campo de la Imagen, que figura un número ocho"; en cambio, lo acusaba por no detenerse en el análisis de la transparencia y ligereza del soporte en tanto verdadero misterio de la práctica de la pintura. ${ }^{25}$ A explicación no pedida, confesión manifiesta y de parte: Conde escribió un capítulo entero para descargar a Cabre-

24. Francisco Xavier Conde y Oquendo, Disertación histórica sobre la aparición portentosa de María Santísima de Guadalupe de México, t. I (México: Imprenta de la Voz de la Religión, I853), 335. Véase también el siguiente trabajo, primero en valorar los razonamientos guadalupanos de Conde y Oquendo y su defensa de Cabrera en contexto de la teoría pictórica de aquel tiempo: Paula Mues Orts, La libertad del pincel. Los discursos sobre la nobleza de la pintura en Nueva España (México: Universidad Iberoamericana, 2008), 319-332.

25. Conde y Oquendo, Disertación histórica, 163. 
ra de un desliz que ya estaba en boca de todos. Para eso pintaba al doctor en medicina como un insolente y cosquilloso petimetre que se cebó con "las piadosas exageraciones" del pintor y se detuvo en "preocupaciones vulgares" para hacer "índice" de un "guarismo [...] con cierto airecillo de victoria, de triunfo". ${ }^{26}$ Para todo lo cual dispuso una "diligencia tan pomposa y tan prolija que se origina únicamente del prurito de impugnar". ${ }^{27}$ Fue tan vehemente su apología que, sin percatarse, el mismo Conde quedó autorretratado o proyectado en sus dicterios tan viscerales y nada razonables. Un ejemplo de su prosa exculpatoria: "Una cosa es mirar como mística alguna señal extraordinaria, y otra cosa muy diferente es hacer misterio de ella, o hacerla servir a descifrar algún concepto oculto de verdad celestial."28

Para empezar, reivindicaba las cualidades como persona moral y facultativa del artista que estaban respaldadas por su identidad como pintor cristiano, cobijado bajo el tópico, tan valorado por el Concilio de Trento, del predicador mudo: "Ni Cabrera era un pintor supersticioso" ni se le podía rebajar en su estatuto de facultativo o profesor: "¿Y qué, yo pregunto, a un hombre tal, en cuyo estilo resplandece tanto la elocuencia [fuese prestada o de casa] no se la ha de dar permiso para tirar un rasgo panegírico y lucir el talento, con la gala de un precioso y gentil concepto, muy ajustado a las circunstancias del tiempo de la aparición y a lo maravilloso de su Imagen?" 29 Todo quedaba acomodado y justificado bajo la licencia poética:

¿Qué historiador, qué orador, aunque sea del genio tan grave y serio como el de Cicerón, ha tenido el valor para desperdiciar un equívoco, renunciar a una antítesis, una paranomasia, u otra de las figuras retóricas placenteras y regocijadas, que en la efervescencia de su imaginación, le hayan venido casualmente a la pluma, y deben mirarse como flores que se encuentran al paso, en medio de la carrera de la oración? Pues yo pregunto, ¿por qué no ha de ser lícito a Cabrera amenizar su leyenda con la sal y la gracia de un conceptillo, no menos religioso y erudito, que obvio y oportuno, como el acomodar el guarismo 8330

26. Conde y Oquendo, Disertación histórica, 347.

27. Conde y Oquendo, Disertación histórica, 347.

28. Conde y Oquendo, Disertación histórica, 348-349.

29. Conde y Oquendo, Disertación histórica, 349.

30. Conde y Oquendo, Disertación histórica, 350. 
Para rematar su catilinaria: lo de Bartolache era una "desvergüenza" infamante, ya que había levantado la sospecha de que atrás de la pluma "lega y doméstica" de Cabrera estaban los jesuitas moviéndole la mano y manipulando en favor de sus propios intereses. En suma, el Manifiesto satisfactorio había desdorado "la probidad y habilidad" de un pintor noble y además reconocido como profesor facultativo. Por eso aquella nota, al pie del grabado del iczotl, con el ocho calcado le pareció hija de una "crítica agria y dura, ¡una inscripción calumniosísima!" hija de unos "cinco pintores que llevaba siempre en la grupa y son los que resuelven en tono magistral y decisivo, que el número ocho no es cosa especial". ${ }^{\mathrm{I}}$

No por acaso a los pintores-analistas los llamaba "pandilla de oficiales", conformando una "comitiva de ladrones" o "turbamulta de delincuentes" y algo había de razón en su desquite. Ya que, más allá de su inquina, el apologista cubano llegó al grado de denunciarlos por cometer un atentado a la integridad de la imagen, casi un sacrilegio. Durante una de las examinaciones - y de manera subrepticia y tramposa-, los maestros de Bartolache rasparon con un instrumento punzocortante varias capas de pigmentos del Sagrado Original con el propósito de comprobar si había aparejo:

Y se pasó a cometer a espaldas del Abad, en atentado de envalentar a uno de sus oficiales de pintura, a que con la punta de una navaja raspase el extremo del ala izquierda de serafín [...] Acción delincuente en realidad, digna del más severo castigo, que al mismo tiempo desemboza el sistema fraudulento de Bartolache, y hace sacar la cabeza al mal espíritu que gobernaba en todas estas operaciones guadalupanas, pero que logró esconder bajo el falso relumbrón de piedad y devoción, con que fue fácil engañar a hombres bondadosos y penetrados de sencillez y caridad cristiana. ${ }^{32}$

3I. En otra pregunta lanzada a su auditorio, Conde y Oquendo también aceptaba que esta cifra podría ser consecuencia de uno de los repintes a la imagen: “Qué especialidad han de hallar los hombres formales en una garambaina del pincel, formada tal vez por aquel pintor travieso que pintó los querubines alrededor de los rayos de la Santísima Imagen?” Cabrera, por su parte, "cometió una bella figura retórica, con aquella gracia especial que nunca podrá tener en la línea de pintura, el garabato se pintó sobre el pie de la Santa Imagen [...] y que todos viven persuadidos, que así como pudo ser un juguete ridículo de algún pincel ordinario de los antiguos; así también la interpretación que da Cabrera, viene a ser parte graciosa de una imaginación viva y exaltada, con el calor de la devoción: epidemia que padecían las bellas letras de aquel tiempo, y de la cual adolecieron principalmente los oradores y panegiristas, como lo fue D. Miguel Cabrera, de Ntra. Sra. de Guadalupe", en Conde y Oquendo, Disertación histórica, 352-354.

32. Lo que Conde y Oquendo pudo comprobar de visu: "Sorprendióle en esta maniobra execrable el padre sacristán mayor del Santuario don Domingo Garcés, quien vive, y me ha asegurado 
DOI: http://dx.doi.org/10.22201/iie.18703062e.2017.1.2593.

I86

Para terminar, Oquendo también subsanó los incómodos silencios de Cabrera respecto a la procedencia de los pigmentos y aceptó que pudieran ser de origen natural, incluso no sólo orgánicos, propios de las flores, sino aun los minerales o procesados por el hombre porque finalmente los ángeles-oficiales los tomaron como productos partícipes de la creación divina y se valieron de ellos para ejecutar sus designios: "Si tal vez criando los colores o valiéndose de los naturales o usuales. Si por ventura sirviéndose de los que sacamos de la tierra y sus minerales, o del jugo de las flores." 33 Este último argumento estaba afianzado conforme a "las pruebas preternaturales" que pedía santo Tomás de Aquino, para aceptar milagros como "señales permanentes", y el asunto central no estaba en la naturaleza de los colores, precisamente, sino en el modo de obrar y disponerlos "sin detención del tiempo" y desafiando el orden de la naturaleza. ${ }^{34}$ Con lo cual, sin percatarse de la contradicción, dejaba sin valor la afirmación de los pintores de 1666 que declararon: "El lienzo por sí y por lo que es pintura, es el más auténtico testimonio del milagro, en un modo tan soberano e incomprensible, que no se puede explicar con la materialidad de nuestro estilo".35 En suma, sin decir una palabra de qué especie de colores se trataba, o de su mixtura y procedencia, este autor aseguraba que la Divina Providencia "lleva a cabo sus efectos", sirviéndose de "las cosas que ha criado como autor de la naturaleza”. Al denunciar finalmente el disimulo, la ligereza, el atentado y la impostura del Manifiesto satisfactorio, Oquendo pensaba que con su apología colocaba para siempre "un candado de hierro en las bocas de Bartolache y su pandilla". ${ }^{36}$

Fray José María Téllez Girón, otro impugnador de Bartolache, igualmente captaba la posición problemática en que había caído Cabrera al consignar, amplificar y significar el ocho y, antes de que esto acabara como burla o prueba de un desliz o desmesura, se apresuraba a absolver al artista con bastante indul-

que el curioso indagador no había sacado más que cierta especie de pelusa del color impreso en el tejido de la trama. Ello es, que hasta el día ha quedado la pintura lastimada e imperfecta, cuya rasura vi y reconocí no sin dolor, el 22 de octubre del año 1785 , que tuve la dicha de venerarla inmediatamente en compañía de don José de Alzíbar, uno de los más famosos pintores de México, con motivo de haberla bajado del altar al plan del presbiterio, a fin de componer su marco y evitar que sobresaliese en términos de causar sombra al bello rostro de la Señora”, Conde y Oquendo, Disertación histórica, 174-175.

33. Conde y Oquendo, Disertación histórica, 216.

34. Conde y Oquendo, Disertación histórica, 222.

35. Conde y Oquendo, Disertación histórica, 22I.

36. Conde y Oquendo, Disertación histórica, 338. 
gencia. El caso es que en su Impugnación de 1792 intentó exonerar a Cabrera de haberse metido a la exégesis mariana:

Es verdad que el primero que produjo la especie del número 8 fue el pintor Cabrera, pero esto no lo asienta como verdad ineluctable que deben todos dar entero crédito. Aquella producción no pasó de un juicio piadoso, que ni al inventor le hizo creer era un signo indeleble como el carácter que traía la sagrada imagen consigo [...] cada uno es árbitro para juzgar sobre lo que ve, y no por esto quiere que vean todos del mismo modo.

Pero lo llamativo en la reivindicación de este franciscano, en pro del prestigio del facultativo pintor, era que se basaba en un argumento del todo simple, real y consecuente, a mi juicio, es el único que hasta la fecha puede pasar como sistemático y probable, que a diario todos experimentamos como fenómeno de la percepción visual y que nos permite configurar el tipo de las imágenes espontáneas:

Cuántas veces por modo de recreación nos ponemos a mirar las figuras que van haciendo las nubes al formarse, y la que a mí me parece un Santiago a caballo otro la juzga por un dragón con su cola. Lo mismo, con proporción hablando, pienso le suceda a nuestro Cabrera. Especulaba la sagrada imagen todo individuo en dominar la pureza que representa de su concepción, y llevado de su devoción o piedad juzgó algún misterio representado en aquella labor que le pareció número ocho, y a los pintores de Bartolache, garabato. Pero no es digno de crítica ni de una discusión exacta en el examen. ${ }^{37}$

\section{Bajo el lente del microscopio}

Los "colores resudados por el envés trastornando las leyes de la naturaleza" han sido motivo de conmoción y la última vez que esto sucedió (de la que tengo noticia) fue la noche del 27 de septiembre de 1982, cuando el restaurador José Sol Rosales realizó una intervención de consolidación y limpieza superficial al ayate a iniciativa del maestro Jorge Guadarrama, conservador de la imagen y director del Museo de la Basílica de Guadalupe. Todo, desde lue-

37. José María Téllez Girón, “Impugnación al Manifiesto satisfactorio del doctor José Ignacio Bartolache" [1792], Testimonios históricos guadalupanos, 687. 
DOI: http://dx.doi.org/10.22201/iie.18703062e.2017.1.2593.

I88

go, en presencia del entonces abad monseñor Guillermo Schulenburg y su arcipreste. Trabajaron hasta las primeras horas de la alborada para no retirar la imagen del culto y con el debido sigilo para evitar "el alboroto". Entonces desmontaron el contramarco, el viejo estuche de acrílico de 1976, casi medio centenar de clavos tachonados que tensaban el lienzo y se aplicó una sustancia: Beva 37I para consolidar tan endeble soporte, y así pudo verse, por tercera vez en la historia, el envés de la pintura y sus colores reventados. $\mathrm{O}$ una suerte de manchones que, en efecto, se habían corrido traspasando la delgada capa de preparación y las fibras de la manta. Entonces se realizó la primera foto de esa otra "Virgen de las flores" y que, como ya hemos explicado, había permanecido censurada para evitar otra "conmoción". Luego de su reporte sobre el estado físico-químico del lienzo y los pigmentos, José Sol Rosales consignó escuetamente: que carecía de barniz, que era difícil encontrar huellas del arrastre de pincel, debido a las técnicas del aguazo usado en las sargas con "el lienzo humedecido para facilitar la fijación del color [y que explicaban también] el fenómeno del sangrado" en el envés. Había otras dos especies de temple: el de cola en el resplandor y el de resina en las manos y rostro (no precisamente óleo) que es la parte más lustrosa. Los paños, como aseguraba Cabrera, estaban trabajados con otra modalidad conocida como temple labrado a base de cola y oro molido. La paleta era restringida e incluso había negro de hollín del humo obtenido del bagazo triturado del corazón de la mazorca del maíz (olote). Era notable la presencia del azul tenido como de origen maya pero logrado por carbonatos de cobre o azurita. Era el mismo y desconcertante color verdemar extraído de los preciosos chalchihuites, según lo ponderaba equivocadamente Conde y Oquendo. El bermellón de la túnica se logró con "azufre y mercurio y el carmín de la cochinilla mexicana", avivando el sangrado posterior. Entonces también ambos pusieron punto final a la discusión entre magueyistas (ixtle) y palmistas (iczotl) abierta por Bartolache al comprobar que el soporte no sólo tenía una imprimatura blanca, lechosa e irregular sino que se trataba de fibras liberianas con características de cáńamo (tal como en otras sargas) y posiblemente extraído de los primeros cultivos importados. ${ }^{38}$

38. José Sol Rosales, "Dictamen de conservación de la imagen de la Virgen de Guadalupe” y Jorge Guadarrama Guevara, "Informe sobre aspectos técnicos de conservación [de la imagen de la Virgen de Guadalupe]", en Fernando Ojeda Llanes, La tilma guadalupana revela sus secretos (México: Miguel Ángel Porrúa, 2005), 212-222 y 230-238. 
En el apartado "materiales extraños a la obra" reportaron diversas manchas por salpicaduras de cuerpos incandescentes o sólidos, específicamente tres de cera. De entre las cuales era difícil saber si el ocho se había formado mediante un hilacho salido de la urdimbre e impregnado de ambos accidentes. Esta mixtura de fibra y adherente, por cierto, no es la mancha de volumen y diámetro más gruesa entre todas las que tachonan y afean la tilma por descuidos e imprudencias. En suma, 230 años después de la inspección de Cabrera, los restauradores mencionados tampoco pudieron comprobar mediante el microscopio si el ocho estaba formado de un derrame de cera de Campeche o de una untura de goma arábiga; pero era sin duda una intervención accidental, que pudiera haberse aplicado desde una candela próxima a la Sagrada Imagen, de entre tantas que se quemaron a sus plantas, en un momento de adoración, o por obra de un retocador descuidado que vertió la ligadura de sus pigmentos o jaloneó un hilacho. La tela de cáńamo, pues, absorbió la pastosidad de la grasa hasta compenetrarse quizá de forma indeleble, introduciendo, aunque involuntariamente, la técnica de la encáustica o una suerte de collage por "accidente controlado".

Así, por obra y gracia de los descuidos de un sacristán (intruso devoto o restaurador segundón) pero, sobre todo, de las laboriosas abejas meliponas de Yucatán, la capa de Juan Diego recibió el más orgánico, concentrado e indeleble de todos sus materiales y bajo el trazo inequívoco de un ocho. Una conjunción de cifra, signo y artilugio posibilitada por una técnica de chorreado formando una pegatina serpentina, sin saberse ahora, hasta que no se tome una muestra, si contiene algo de cera, goma o resina. A mi gusto lo mejor será pensar que sea de cera.

La especie de abeja meliponini es campechana de origen y ahora cultivada en forma exclusiva en la América atlántica: se le explota desde el norte de México hasta el norte de Argentina, y es tan apreciada por ser sociable, carecer de aguijón y porque su concentrado de cera y mieles se expende muy bien por las tantas propiedades curativas que posee (como el famoso propóleo para aliviar la tos); tanto así que no sólo los mayas la tuvieron por animal sagrado sino que por sus efectos, casi milagrosos, hoy se vende bajo la etiqueta de la Divina Providencia. La Divina Providencia, que es la manifestación de la voluntad de Dios sobre la historia, que siempre ha sido considerada la verdadera autora, en su representación trinitaria, "de tan celestial pintura", es una de las marcas de las ceras, igual sintéticas parafinas, más vendidas, que ahora mismo se consumen en el quemador del santuario del Tepeyac. 
DOI: http://dx.doi.org/10.22201/iie.18703062e.2017.1.2593.

190

\title{
La guerra: del 1808 insurgente al octavario revolucionario
}

Es posible que la mirada devota de Cabrera y Echeverría y Veytia de I75I haya generado un falso problema o una simple charada, sin meditar demasiado en sus consecuencias, pero ya hemos visto que sus lucubraciones no pararon allí: se politizaron con acrimonia. El caso es que otros autores asimilaron a su modo los accidentes de esta "imagen espontánea" y así analicemos tres de las consecuencias de sus impredecibles deslizamientos de significado.

En primer lugar, nada menos, la opinión del jansenista arzobispo de México Lorenzana - luego cardenal de Toledo, primado de España-, que llegó a expresar el más palmario y contundente de todos los significados, hasta aquí acumulados, en un sermón solemne luego de la expulsión de los jesuitas y en el que aseveraba, llamando a la unión de americanos y españoles: "Pues alegraos hijos naturales, convidad y llamad indio a todas las gentes para que alaben a nuestra reyna y se alegren con nosotros de tener aquí, no la octava maravilla del mundo, sino la primera, pues aunque en la túnica tiene unidos dos círculos, que parecen un ocho, son los dos mundos que protege." 39

Tampoco faltó una lectura profética y en clave liberadora al significado del número ocho en la pluma de un poeta criollo, que por medio de la ambigüedad lamentaba al mismo tiempo la crisis de la monarquía de i808 o auguraba, como canción de gesta, la emancipación política tan inminente por aquellos años:

\author{
El número ocho tiene \\ En la rosada túnica, y previene \\ De este cifrado modo \\ Que habrá de libertar el reino todo, \\ Por su alta mediación, \\ De alguna cruel, tiránica invasión; \\ Nueva España, estarás serena, afable, \\ En ochocientos ocho memorable. ${ }^{40}$
}

La aplicación de significado que entonces hizo el escéptico Lorenzana partía de una cifra, que se transmutaba en signo pero que no dejaba de ser un artilugio.

39. Francisco Antonio Lorenzana, Oración a la Virgen de Guadalupe (México: imprenta del superior gobierno del bachiller Joseph de Hogal, I770), XXXI.

40. Peñalosa, Flor y canto de poesía guadalupana, I73. 
De paso quedaba bien con su público y les recordaba a los criollos su condición políticamente subordinada. Pero al cabo, como ha señalado William Taylor, esta operación no hubiese sucedido si el ilustrísimo prelado no conviniera en un arreglo entre su mentalidad y su fe, mirado aquel objeto venerado con la investidura de la inmanencia, una propiedad tan justificativa como indulgente. ${ }^{4 \mathrm{I}} \mathrm{La}$ inmanencia es un valor agregado a toda representación sagrada ya que es inherente a su prototipo y de algún modo le queda unido y la expresa en un signo; es más, la inmanencia era inseparable de la esencia del numen, aunque racionalmente cada persona — si se lo propone-, puede distinguir la valencia de esta última de lo que físicamente contempla en la naturaleza de cada objeto. Se desempeña, pues, como un conectivo emocional entre sus signos visibles con la divina presencia, para demandar lealtad entre las dos Españas o de plano con el sentido acomodaticio del soneto insurgente.

No deja de ser parte de la vida de una imagen el traspaso de sus contenidos semánticos a otro contenedor simbólico. O cuando los saberes eruditos quedan sedimentados en la cultura popular y desde allí se reactivan en otro nivel de significado: el hábito de "contar cuentos" fue hasta hace poco un derecho de las clases subalternas y, según Robert Darnton, una legítima expresión del "mundo mental de los no ilustrados" o que se resisten a pensar conforme a las reglas de la Ilustración. ${ }^{42} \mathrm{Si}$ el ocho acabó entre veras y burlas de los ilustrados y revivió como un signo de los tiempos durante la Independencia, volvió por sus fueros en medio de la crisis de la Revolución mexicana. Pasada la Decena Trágica, la ejecución del presidente Madero - y el derrocamiento de Victoriano Huerta en agosto de 1914-, esta cifra pudo ser igualmente interpretada como una señal venturosa u ominosa de los tiempos. $\mathrm{O}$ al menos bajo la perspectiva de quien desde la prensa administró el significado del signo para generar una nueva "conmoción". Un cuadernillo de ocasión salido de la imprenta de Antonio Vanegas Arroyo, situado entre el género piadoso de la novena de rezo e imprecación y el folletín de sensación, titulado: Visita a María Santísima de Guadalupe... ${ }^{43}$

4I. William B. Taylor, Shrines and Miraculous Images, Religious Life in México before the Reforma (Albuquerque: University of New Mexico Press, 2010), I5-62.

42. Robert Darnton, La gran matanza de gatos y otros episodios de la Revolución francesa, trad. Carlos Valdés (México: Fondo de Cultura Económica, 1987).

43. Visita a Maria Santísima de Guadalupe, precedida de una completa noticia de la aparición del número 8 en el manto y seguida de oraciones, ofrecimiento, letanía, salutación (México: imprenta de Antonio Vanegas Arroyo, 1915). Las siguientes citas provienen de ese folleto. 
DOI: http://dx.doi.org/10.22201/iie.18703062e.2017.1.2593.

I92

En su docena de páginas, se avisa a los lectores y a "la Nación entera" que se harán dos anuncios inauditos pasada la pesadilla de la dictadura huertista y ante el descontrol de autoridad por carecerse de un mando federal. Aparte de la reaparición del ocho "en el manto" original, se narra previamente la aparición de un arcoiris de alborada — del todo inexplicable—, tras los cerros del Tepeyac y augurando "una señal de paz". Este fenómeno tan sólo fue detectado por un canónigo madrugador, extasiado y perplejo, que por lo mismo no supo si de esa forma se anunciaba desde el cielo una nueva alianza de paz, "pasado el Diluvio". De esta manera admonitoria comienza la "parte histórica", para luego dar paso en las hojas finales a las oraciones y letanías:

En enero de I9I5, época precisamente en que las agitaciones políticas del país llegaban a su intensidad máxima con motivo de la revolución iniciada por el señor Francisco I. Madero desde diciembre de I9Io, y estando como presidente provisional de la República el general revolucionario Eulalio Gutiérrez, que fue designado por la Soberana Convención de Aguascalientes, toda la sociedad metropolitana y la nación entera, por medio de la prensa diaria, fue poderosamente despertada de su marasmo religioso al anuncio del último milagro de la poderosa reina del cielo y patrona de la nación mexicana, nuestra madre Santísima de Guadalupe que se venera en su Colegiata de México.

Pasados tres días, sucede el descubrimiento del ocho que supuestamente provocó una conmoción popular $y$, sobre todo, que quedó patente al verse multiplicado en cada copia de los altares domésticos:

Se trata nada menos que de la aparición de un signo en el manto de la Virgen de Guadalupe; signo que tiene la figura del número 8 y que repentinamente ha aparecido en muchas de las imágenes de la reina de México. Este suceso raro y maravilloso es objeto de una general admiración de todos los habitantes, con cuyo motivo puede verse diariamente una perpetua romería ávida de ver por ojos propios, el singular signo o sea el número 8. Naturalmente que este hecho ha causado más impresión de ánimo con los diferentes sucesos que han tenido lugar en la misma Villa de Guadalupe Hidalgo (fig. I2).

Todo esto desencadenó reacciones individuales y colectivas, pero el articulista se reserva ponerles nombre y apellido. Las autoridades eclesiásticas se pronuncian o al menos cubren el expediente para que no dé lugar a la superstición o el fanatismo... aunque éste sea, precisamente, el resorte que suscitan las ven- 
I2. Antonio Vanegas, ed., "Memoria de la aparición del número 8, en el manto de la

Virgen de Guadalupe", en

Visita a Maria Santísima de

Guadalupe. Precedida de una nota completa de la aparición del número 8 seguida de oraciones, ofrecimientos, letanía, salutación, I9I5, folleto, $27 \times 18.2 \mathrm{~cm}$, s.p. Colección particular, Ciudad de México.

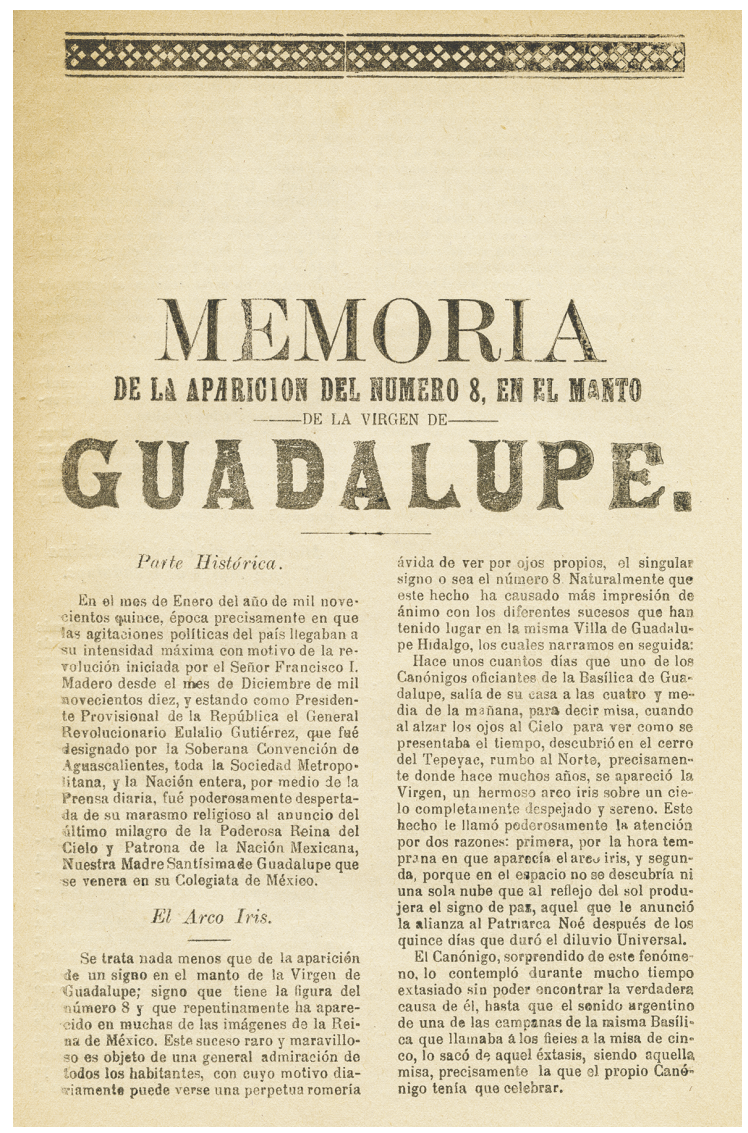

tas del impresor "sacatlacos". ${ }^{44}$ Por eso mismo, para pasar de lo inverosímil a la credibilidad, enseguida se recogen las aseveraciones del canónigo visionario y sus declaraciones tienen que darse en tono profético, propiamente un presagio:

44. No era la primera vez que esta casa editorial se ocupaba de los portentos guadalupanos. Lo hizo en I894 con el sonado caso de una imagen grabada en un maguey hallada en el rancho de Lechería que ameritó la traslación del mismo. Un año después dio seguimiento puntual a las fiestas de la coronación pontificia. En I908 recogieron la explosión de un horno de pan cerca de Zamora, Michoacán, todas ilustraciones muy conocidas de Posada. Estos impresos pertenecen al género de hojas volantes que, según sus editores, "se publican cuando los acontecimientos de sensación lo requieran”. Tal como ha estudiado Helia Bonilla, las hojas o los cuadernillos no sólo se voceaban por un pregonero popular afuera de los mercados y los templos sino que se enviaban por vía postal 
el canónigo afirma, asegura y sostiene que lo vio distintamente sin tener duda de haberse equivocado ni que sea una alucinación simplemente; pero sí asegura, que la paz de la nación no dilata, puesto que así lo sintió al ver el arco iris y cree firmemente que la madre guadalupana así lo haya anunciado [...] A los tres días de haber aparecido el arco iris en el cerro del Tepeyac, uno de los fieles que concurren asiduamente al templo de la Virgen y que es su más ferviente devoto, al dirigir sus ojos en éxtasis al cuadro de la guadalupana, descubrió el número 8 en el manto de la Virgen, en la parte inferior, encima precisamente del ángel que yace a los pies de la imagen. Esta visión no le extrañó al pronto culpando que era la poca luz; pero más tarde al final de la misa lo volvió a ver y ya intrigado por la aparición, se lo hizo notar a uno de los fieles que tenía a su lado, éste al pronto no vio el número 8 , pero cuando sus ojos se acostumbraron en la oscuridad, lo vio también lo mismo que las demás personas a quienes avisaron de la extrańa aparición. Como era natural, el suceso corrió de boca en boca y todo el mundo católico y aún los más ciegos impíos ocurrieron al templo para contemplar el fenómeno que todavía está impreso en el manto de la Virgen María.

Lo mismo que sucedió entre los descubridores y los apologistas del siglo XVIII, todo quedaba acreditado por una autoridad del clero que se mantiene en la reserva "para no alborotar al populacho", el expertise de los conocedores (ahora en calidad de anónimos) y la vox populi que es incontestable, pero al cabo es otra forma de permanecer en el anonimato. La parte final de esta narrativa era un requisito indispensable, al establecer la exégesis esperanzadora de la cifra, que es lo que el público pide, pero con la debida e indulgente ambigüedad para interpretar el signo:

Comenzaron los comentarios cada cual a su manera y no ha faltado quien asegure que la aparición del 8 será señal de paz. Mas el milagroso suceso tiene algo de trascendencia como lo vamos a ver enseguida. El milagro de la Virgen de Guadalupe es muy grande — nos ha dicho una eminencia del clero. La patrona de México

\footnotetext{
a buena parte del territorio nacional e igualmente eran criticados por los liberales ilustrados como "supercherías inventadas para explotar el fanatismo" por "explotadores del candor" (llamados "sacatlacos") que por algunos sectores de la jerarquía preocupados porque se "engañaba la sencillez de los fieles con 'supercherías para especular". Helia Bonilla Reyna, "Fortunas e infortunios del impreso popular ilustrado por Posada”, en Posada, el genio de la estampa, ed. Mercurio López Casillas (Aguascalientes: Instituto Cultural de Aguascalientes/Consejo Nacional para la Cultura y las Artes, 2010), I05-I48.
} 
quiere demostrarnos que está con nosotros como que es la madre de los mexicanos y que difícilmente nos retirará su valiosa protección y más en las actuales circunstancias porque atraviesa la patria.

Por último, no deja de aparecer el personaje del escepticismo propio de la era racional ("los ciegos impíos"), que al igual que Bartolache también resulta un testigo de parte..., pero que al cabo se rinde ante la evidencia colectiva:

Nosotros no pertenecemos al grupo de personas que se alucinan con cualquier hecho insignificante, pero el suceso o milagro del cual nos ocupamos, sí nos llama la atención en vista de que el mismo número 8 ha aparecido en gran cantidad de imágenes de la Santísima Virgen de Guadalupe, circunstancia que tiene profundamente confundidos a los propietarios de ellas. No creemos necesario publicar la larga lista de nombre de los dueños de distintas imágenes, más lo cierto es que se forman gran número de peregrinaciones que van de casa en casa viendo con admiración y gran asombro el mismo número 8.

El acertijo de la cifra se resolvió en la siguiente reimpresión del cuadernillo que declaró a plana entera: "El día 8 de febrero del presente año quedará asegurada la Paz de la Nación por medio del milagro de la Virgen Santísima de Guadalupe."45 No se olvide que apenas, desde el 6 de diciembre de I9I4, las tropas de Villa y Zapata habían tomado la Ciudad de México y ocupaban el Palacio Nacional (y Carranza al huir se llevó la representación federal a Veracruz). El presidente interino de la República, Eulalio Gutiérrez, tuvo que escapar el i6 de enero para establecer su investidura en San Luis Potosí. Las tropas constitucionalistas lidereadas por Obregón recuperaron la capital el 26 de enero de 1915, previa huida de los ejércitos del sur y la División del Norte. ${ }^{46}$ Este último no sin atemorizar aún más a los habitantes de la capital y al

45. Mi agradecimiento a la amistad y generosidad de Helia Bonilla que me proporcionó copia de este último ejemplar y despejó todas mis dudas sobre el modus operandi de Posada y las prácticas de la imprenta de Vanegas Arroyo.

46. "En esta ocasión, la actitud de Obregón fue más drástica contra los comerciantes: el i8 de febrero emitió un decreto que establecía una contribución forzosa del Io\% de sus mercancías, con las que se establecerían puestos de aprovisionamiento para la población; la mayoría de los comerciantes ignoraron el decreto y el 25, Obregón emitió un segundo que establecía una contribución forzosa sobre capitales, predios, hipotecas, profesiones, patentes, automóviles y otros bienes, válido tanto para propietarios nacionales como extranjeros. Convocó a una junta a los comer- 
mismo clero por el régimen de imposiciones y privaciones que impuso. Se vivía, pues, en medio de la zozobra y el pillaje, pero igual el fervor de una religiosidad campesina y proletaria desde que las tropas del sur entraron con su estandarte guadalupano o sus estampas calzadas en el sombrero. Por el contrario, la última semana de enero se sintió el primer manotazo de los carrancistas jacobinos que cimbró a la iglesia, y transmitió a sus fieles la percepción de que el estado nacional quedaba diluido; pero sobre todo quedó cerrada la posibilidad de alejar la discordia y la violencia. La fabricación del milagro del ocho tuvo que ocurrir entre esa fecha ( 26 de enero) y la primera semana de febrero cuando los editores se lamentaban del régimen militarizado y posiblemente apostaban al retorno de las fuerzas populares del norte y del sur.

En una segunda entrega, Vanegas intentaba estabilizar el caos augurando la esperanza de un acuerdo entre las partes e invocando la participación hierofánica de la Guadalupana. En 24 cuartetas se contaba el milagro cifrado entre el iris y el $o c h o$, al tiempo que los creyentes se movilizaban expectantes detectando el ocho en sus imágenes caseras:

La Paz ya pronto es un hecho,
dice el clero mexicano
y se acabará la guerra
guerra de hermano a hermano.
Pues si el iris no vastó $[s i c]$
para fe tener en ti,
un 8 apareció
que mi vista contempló

Ese 8, Virgen María, de la paz será la fecha y permite que sea hecha, ya que tú nos las envías

El 8 ha aparecido en la punta de tu manto y con él se acabará de nosotros el quebranto.

ciantes que se habían negado a pagar la contribución y apresó a los nacionales, soltándolos una vez que hubieran pagado. Esta misma actitud jacobina la tuvo con respecto al clero capitalino al que obligó también a pagar una contribución, después de haber detenido a algunos clérigos. Estas medidas lo enemistaron con estos sectores y con los miembros de las delegaciones extranjeras, que comenzaron a protestar por lo que consideraban excesos de Obregón y a presionar a Carranza para que desalojara la capital [...] la indignación de muchos sectores por el anticlericalismo recalcitrante de algunos jefes constitucionalistas, hicieron esos días particularmente difíciles para la población citadina que, ante la falta de alimentos, comenzó a acudir a las zonas periféricas en busca de yerbas silvestres y escudriñar los basureros en busca de restos con que alimentarse", en Felipe Arturo Ávila Espinosa, "La Ciudad de México ante la ocupación de las fuerzas villistas y zapatistas. Diciembre de I9I4-junio de I9I5", en Estudios de Historia Moderna y Contemporánea de México, núm. I4 (I99I): II5, I22-I25. 
Populo locuto, causa finita, est, parece decirnos el articulista. Pero la noticia de sensación no deja de encerrar una terrible paradoja: que en lugar de un nuevo iris de paz, el signo de este ocho reaparecido resultara del todo ominoso para la propia Iglesia mexicana. Ya por las inminentes leyes restrictivas carrancistas como por el ataque a las imágenes sagradas por parte del ejército constitucionalista tan proclive a profanar y conculcar los recintos eclesiásticos.

La persistencia de "contar cuentos" es sorprendente y apasionante, pero lo es igual la intervención y reconfiguración de una imagen para nuevos usos. La plancha que Posada había abierto para las fiestas de la coronación de 1895 fue la misma que un entallador anónimo modificó con su bruñidor dos décadas después, ahora como prueba visual o "ilustración científica" del prodigio. En esos días de enero de 1915 raspó con torpeza sobre los arabescos de la túnica y así reluce — casi con efecto fluorescente- un aparatoso ocho que por exagerado ahora provoca un efecto contraproducente. Pese al anacronismo del discurso y sus préstamos, la aspiración de los "no ilustrados" era del todo legítima y vigente: al tiempo en que se "retrabajó" el grabado, en un contexto de crisis y amenaza, resurge una historia de filiación marial-apocalíptica que momentáneamente intenta estabilizar "el quebranto" y "la agitación" de la patria y detener el tiempo en un espacio ensangrentado por la lucha fraticida (fig. I3).

No en todas sus versiones de la Guadalupana, el grabador Posada incluyó esta cifra, pero al menos quedó registro en una: el Juan Diego tenante que despliega y muestra su capa estampada. Al validar la tradición de las "verdaderas efigies", sumó el ocho al final de los arabescos siguiendo el modelo de rasgos abiertos de Bartolache (fig. 14). La herencia de Cabrera no sólo estaba viva en el tipo de indio con balcarrotas sino en este detalle, aparentemente tan nimio, que apenas rescatamos o incluso también alucinamos si acaso esto no es verdad, un engaño de nuestra vista o mera casualidad. El ocho descomunal de los Vanegas Arroyo de 1915 no sólo fue un mal presagio para el futuro quizá también fue el obituario de una tradición popular que, al parecer, desde entonces anunció su salida de circulación en el arte del siglo xx (salvo la excepción desconcertante que mencionamos arriba en la tradición de los cromos almanaque de González Camarena). Es también revelador que el más solicitado copista guadalupano de entonces, el incansable padre Gonzalo Carrasco, alentado por su militancia cristera y al gusto que su pintura desarrolló entre la clase católica media y alta, haya mantenido en algunas ocasiones esta cifra quizá por considerarla un signo de la tradición que moría con él. ${ }^{47}$

47. Para conocer la intervención subrepticia que borró la corona de la imagen guadalupana y sus implicaciones políticas puede verse: Jaime Cuadriello, "La Reina sin corona”, XXVIII Coloquio 
DOI: http://dx.doi.org/10.22201/iie.18703062e.2017.1.2593.

198

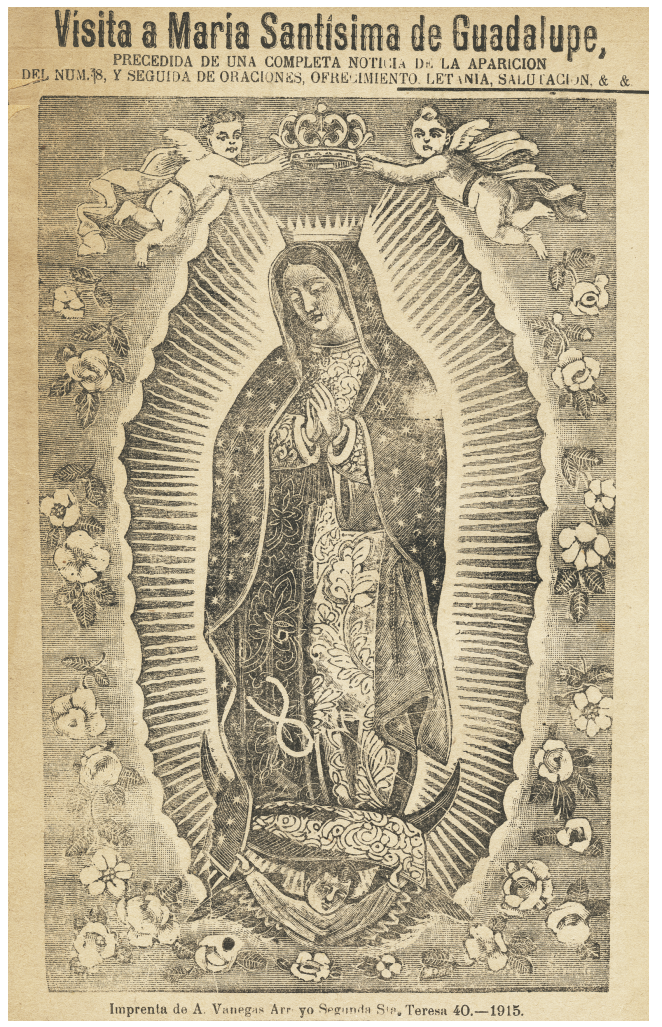

I3. José Guadalupe Posada, grabó en I895, autor desconocido modificó en 1915, Visita a María Santísima de Guadalupe. Precedida de una completa noticia de la aparición del núm. 8 y seguida de oraciones, ofrecimiento, letanía, salutación, 1915, folleto, $27 \times 18.2 \mathrm{~cm}$. Colección particular, Ciudad de México.

\section{Arquetipos primigenios, artilugios sintéticos}

En suma, si miramos con ojos actuales, luego de la inspección de Cabrera y Echeverría y Veytia sucedió aquella operación de la mente que exploró Carl Gustav Jung o cuando las expectativas no cumplidas retrotraen al inconsciente colectivo los arquetipos primigenios y que, de pronto, se materializan en imágenes oníricas o miríficas o donde la mirada epocal hace su parte: las metarrepresentaciones (fig. 15$).{ }^{48}$ En verdad, en 175 I había tenido lugar una metarrepresentación de repentino, perceptible y comprensible sólo para

Internacional de Historia del Arte. La imagen sagrada y sacralizada, vol. II, ed. Peter Krieger (México: Universidad Nacional Autónoma de México-Instituto de Investigaciones Estéticas, 20II), 65I-680. 48. Carl Gustav Jung, Arquetipos e inconsciente colectivo, trad. Miguel Murmis (México: Paidós, 2009). 
DOI: http://dx.doi.org/10.22201/iie.18703062e.2017.1.2593.

I4. José Guadalupe Posada, Coloquio para celebrar las cuatro apariciones de la Virgen de Guadalupe, 1913, $17 \times 10 \mathrm{~cm}$. Colección particular, Ciudad de México.

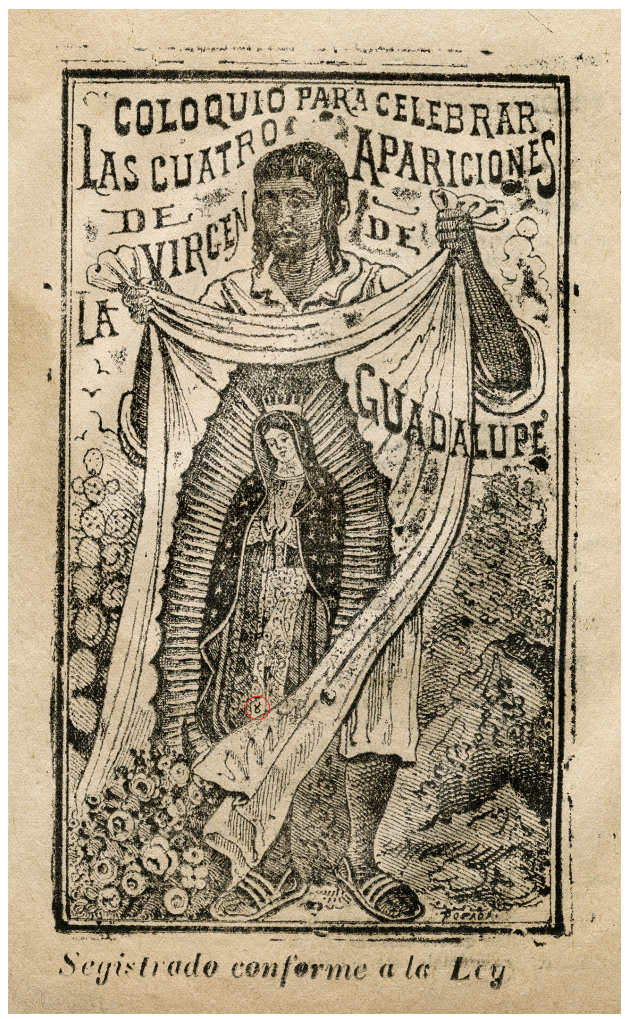

los iniciados: imágenes que registraban la visión desde una especie de ectoplasma informe y que la imaginación reconfiguraba mediante un juego dinámico e inteligible de signos, pero donde las estratagemas de la retórica hacían la mejor parte. Para Echeverría y Veytia posiblemente era un indicio viquiano de aquellos otros que la Providencia "oculta en el objeto" para constatar al cabo la "naturaleza común" de las naciones. ${ }^{49}$

Tampoco es casual que Cabrera y sus promotores jesuitas se hayan servido de los instrumentos retóricos. O bien ajustando ese "catalejo para bien mirar" descrito por el conde Emanuel Tesauro en su multieditado y traducido Cannochiale Aristotélico de 1655 (fig. 16). Este libro es un amplio repertorio de recursos retóricos y visuales, que servía por igual a predicadores y pintores para

49. Álvaro Matute, Lorenzo Boturini y el pensamiento histórico de Vico (México: Universidad Nacional Autónoma de México-Instituto de Investigaciones Históricas, 1976), 4I-57. 
DOI: http://dx.doi.org/10.22201/iie.18703062e.2017.1.2593.

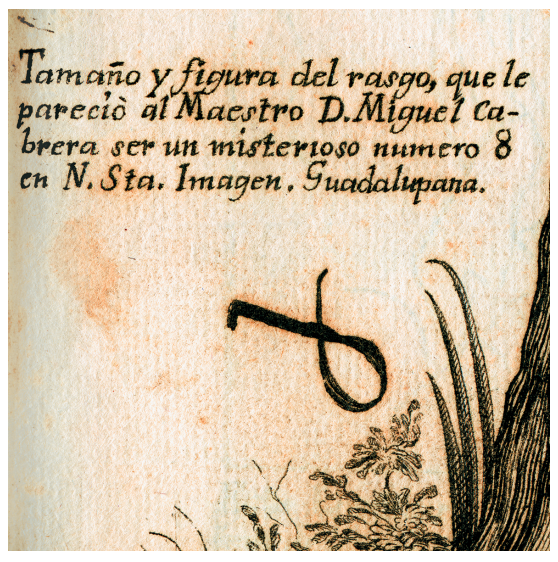

I5. Anónimo novohispano, detalle de Iczotl, ca. $1787, \mathrm{I} 8.3 \times 13.5 \mathrm{~cm}$, tomado de Bartolache, Manifiesto satisfactorio (vid supra $\mathrm{n}$. I8).

agudizar sus argumentos y zanjar los problemas de la representación, y penetrar, por obra de la retórica, en los significados más ocultos de los signos. Pero, como bien ha visto José Emilio Burucúa, Il Cannochiale también sancionaba toda ambivalencia de significado incluso "para dilucidar los problemas de las contradicciones y de los límites cognitivos de la visibilidad". 50 Merced al recurso y discurso de dirigir la mirada, gracias al paragone o a la hermandad de la Poesía y la Pintura, se obtenía el efecto deseado y casi obsesivo de persuadir: "Las cuestiones de la verdad y el engaño, de las metamorfosis de la una en el otro y viceversa, del carácter irreductiblemente anfibológico de las representaciones." ${ }^{\text {'1 }}$ En el frontispicio alegórico de esta obra, la personificación de la Poesía es capaz de descubrir y escrutar las manchas solares (casi las mismas imperfecciones de María de Guadalupe vestida de sol), pero ayudada de la Filosofía y la Ciencia mediante un impensable oxímoron entre los métodos de Aristóteles y Galileo. Al tiempo que la Pintura mejoraba las manchas de la estrella y describe lo inefable y lo imposible, merced al artilugio de un espejo cónico, o por medio de una anamorfosis que anuncia el maridaje entre ambas: "Todo en uno". Sin todas ellas resulta imposible conmover y persuadir: en su afán de mejorar las imperfecciones de la realidad, son "mujeres fabricantes de ficciones, pero contradictorias sirvientas de la verdad". 52

50. José Emilio Burucúa, Historia y ambivalencia, ensayos sobre arte (Buenos Aires: Biblos, 2006), I2I.

51. Burucúa, Historia y ambivalencia, ensayos sobre arte, I2I.

52. Burucúa, Historia y ambivalencia, ensayos sobre arte, 127. 
DOI: http://dx.doi.org/10.22201/iie.18703062e.2017.1.2593.

I6. Domenico Piola, dibujó, Georges

Tasniere, grabó, I670, frontispicio de: Emanuel

Tesauro, Il Cannochiale aristotelico. O'sia, idéa dell'arguta et ingeniosa elocutione che serve à tutta l'arte oratoria, lapidaria et simbolica esamita co' principii del divino Aristotele (Turín: Bartolomeo Zauatta, I670). Colección particular, Ciudad de México.

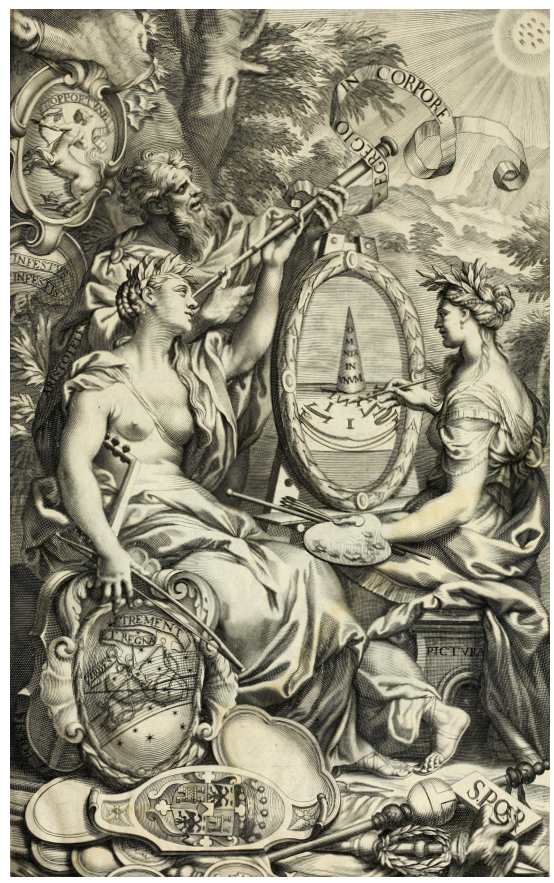

En medio de esta misma poética y política de "peregrinas y metafóricas operaciones que hacen incrédulo a quien no las ve y a quien sí las ve le hacen creer lo increíble", en los últimos 50 años (una era neobarroca) no han menguado los análisis pseudocientíficos guadalupanos, o peor aún, una especie de ciencia ficción aplicada a la imagen, todos basados en el supuesto de la resolución de enigmas (fig. I7). Menciono alguna de estas "tesis" que han ganado infinidad de adeptos o la sonrisa escéptica, incluso, de algunos sacerdotes: las pupilas de la Virgen como registros fotográficos del retrato de Juan Diego; la túnica y el manto vistos como códice pictográfico que renueva a la antigua diosa Teotenantzin; la partitura musical y celestial escrita secretamente entre los arabescos y las estrellas o la carta astral del manto que prueba la perfecta alineación de las constelaciones aquella madrugada del I2 de diciembre de I53I. Si aún estuviera vigente el Tribunal de la Fe del Santo Oficio, no dudo que todos estos autores, excedidos y extraviados a causa de su propio ingenio, quedarían instruidos bajo proceso de ilusos, alumbrados y embaucadores, peor todavía a la gravedad de la causa seguida y padecida por fray Servando; pero, paradójicamente, muchos 
DOI: http://dx.doi.org/10.22201/iie.18703062e.2017.1.2593.
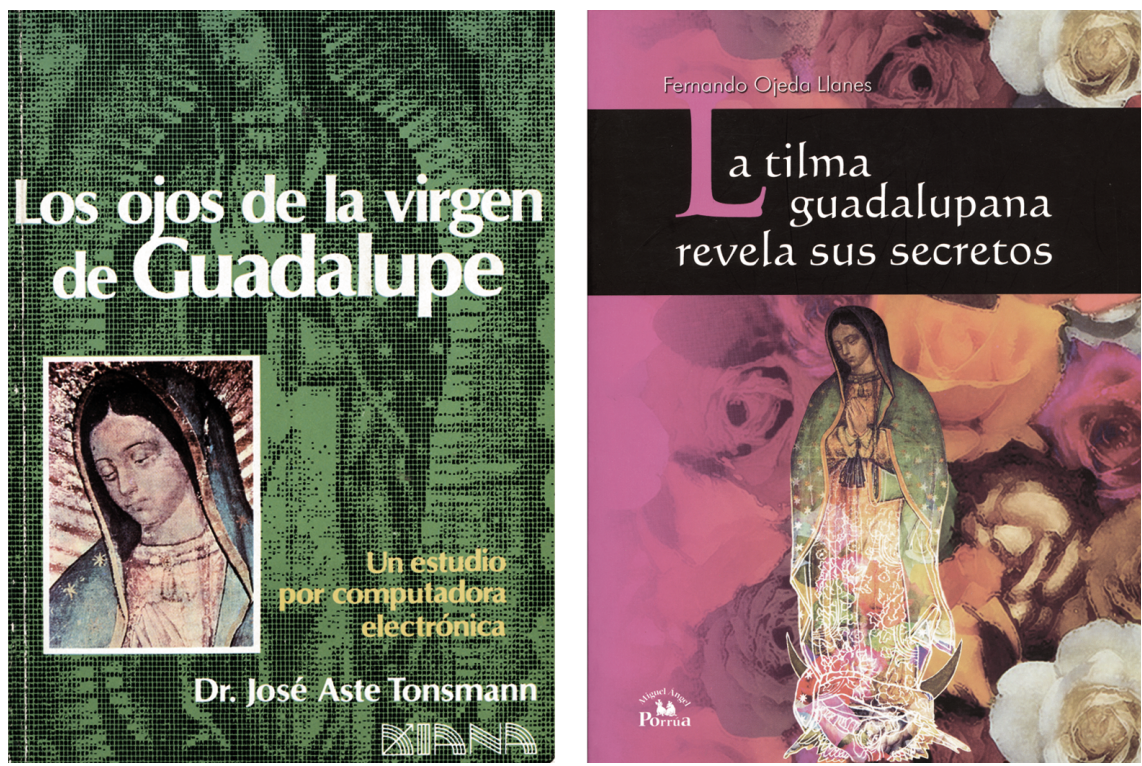

I7. Portadas de libros guadalupanos. (CFotos: Fernando Herrera.

de estos libros "que alborotan al populacho" gozan del nibil obstat eclesiástico y son prohijados por una parte de la jerarquía.

Hay que decir, por último, en descargo de las vaguedades y vanidades del propio Bartolache, que el Manifiesto satisfactorio representa a un autor amigo de Galileo, que miraba con su nuevo telescopio, mientras sus contemporáneos, como los de hoy, seguían y siguen aferrados al catalejo de Aristóteles y sus lentes anamórficos o deformados. Al igual que los conservadores que en I982 vieron al microscopio la verdadera naturaleza de los pigmentos y fibras, que hicieron ostensible su idea del conocimiento guiados por el acto de mirar, observar, describir y comenzar a escrutar, como pocos, en los hasta hoy silenciados análisis de los materiales.

Pero como hombres simbólicos junguianos seguimos aferrados a los significados y sus artilugios, por ser tan elocuentes por lo que cuentan y cuentan para el imaginario social. En esta constelación de alucinaciones, el ocho desde luego ha vuelto por sus fueros y es ahora un signo egipcio-caldeo del universo eterno, obra de la Providencia divina "que se resuelve a sí misma" desde el 
I8. Tatuaje con el Ouroboro en forma de ocho, símbolo del infinito y la eternidad. (CFoto: Fernando

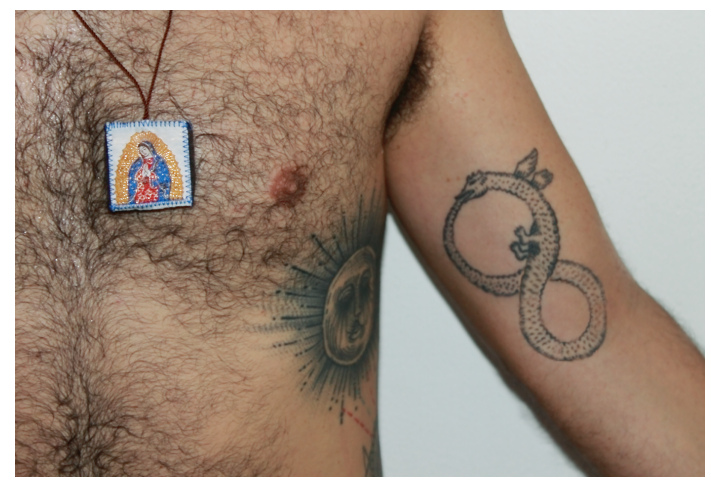

infinito. ${ }^{53}$ Merced a la obra de Horapolo que transmitiera en su Hieroglyphica estos saberes ancestrales al neoplatonismo del Renacimiento, resurge este significado que alcanza ahora mismo la tilma milagrosa y, en medio de la cultura new age, a tantos practicantes del tatuaje indeleble que lo graban con tintas en piernas o brazos para asegurarse, desde su organismo perecedero, la trascendencia al infinito: un lugar permanente en la otra vida o un pasaje seguro a la Eternidad (fig. 18). Ya vimos cómo Conde y Oquendo despachaba el asunto como si se tratase de una garambaina o garabato con el que tropieza cualquier panegirista: "parte graciosa de una imaginación viva y exaltada con el calor de la devoción: epidemia que padecían las bellas letras de aquel tiempo". 54 No por nada decía el fraile Téllez Girón en I792, también de una manera traviesamente falaz y juguetona: "Cuántas veces por modo de recreación nos ponemos a mirar las figuras que van haciendo las nubes al formarse: si uno las juzga caba1lo, otro las mira dragón con su cola."'s5

La certeza misma de nuestro conocimiento histórico entra en crisis cuando se tropieza con la yuxtaposición de los anacronismos y puntos de vista, así Didi-Huberman parafraseaba una reflexión de Walter Benjamin, a propósito de las imágenes que se generan por azar en el caleidoscopio o los "rompecabezas chinos" y más aún si están en manos de los niños:

53. Horapolo, Hieroglyphica, ed. Jesús María González de Zárate, trad. María José García Soler (Madrid: Akal, I99I), 46.

54. Conde y Oquendo, Disertación histórica, 353-354.

55. José María Téllez Girón, “Impugnación al Manifiesto satisfactorio, del doctor José Ignacio Bartolache”, en Testimonios históricos guadalupanos, 687. 
La palabra bretzel, existente en francés a finales del siglo XIX, viene del latín vulgar brachitella, diminutivo de brachita, de brachium, "brazo". Designa — por analogía de forma, de Urform - un panecillo liviano en forma de 8 de brazos entrelazados, salado y espolvoreado de comino. Si se lo emplea en otro sentido, el bretzel dibuja algo que se vincula al símbolo del infinito, lo que daría un sentido muy profundo a la frase del pequeño filósofo: el tiempo se lanza como un bretzel en la naturaleza. ${ }^{56}$

En cualquier panadería tradicional mexicana — tan influida por la francesa desde el siglo XIX—, aún se despacha el bizcocho llamado ocho. \$

56. Didi-Huberman, Ante el tiempo. Historia del arte y anacronismo de las imágenes, 212-213.

N.B. Aclaración sobre las ilustraciones. Luego de haber realizado el trámite correspondiente ante el Museo de la Basílica de Guadalupe para ilustrar con algunas de sus obras este artículo y de haber sido aceptada mi solicitud, la directora del mismo me envió una carta con fecha del 4 de abril de 2016. En ese documento se condicionaba la reprografía a la entrega de este texto para su dictamen por el Instituto Superior de Estudios Guadalupanos. Tal petición me situó ante una disyuntiva ética y profesional, ya que comprometía y afectaba mi libertad de investigación y pensamiento. La entrega de mi trabajo implicaba la lectura, dictamen y posible censura por esa asociación civil. Tomé la decisión irrevocable de prescindir de las imágenes solicitadas, dado que aceptar hubiera significado ceder ante un procedimiento anormal e irregular que dejaría un precedente tanto en la institución como en mi carrera. Además de vulnerar el espíritu de libertad de pensamiento que sostiene la Universidad Nacional Autónoma de México, que finalmente es el editor y quien ha dictaminado positivamente este trabajo, mediante colegas pares, anónimos y especialistas en mi campo de conocimiento. Así se lo comuniqué a la directora. Desconozco las razones o el estatuto del Instituto Superior de Estudios Guadalupanos para proceder de esta manera, manifiesto mi extrañamiento y refrendo mis deseos para que estas situaciones, que implican una definición moral con el saber y el deber, no vuelvan a ocurrir. Para remediar la articulación visual y dar idea del valor de los materiales, el lector hallará unos croquis realizados por el maestro Fernando Herrera Valdez que sustituyen, al menos en su iconografía, las obras que resguarda el Museo de la Basílica de Guadalupe. Mi agradecimiento a sus dotes artísticas y también a Iván Martínez Huerta por su compañerismo al seguir puntualmente este proyecto, cuidarlo, y su aportación de los materiales que amablemente nos suministraron los descendientes de Antonio Vanegas Arroyo. Un primer avance de este trabajo se presentó en el coloquio-homenaje: William B. Taylor Scholarly Inquietudes an Interdisciplinary Workshop en la Universidad de Harvard, Cambridge, Massachusetts, el 4 de octubre de 20I4, estoy en deuda con el profesor Taylor por sus palabras, generosidad y el obsequio de su amistad. 